\title{
CLINICAL OBSERVATION AND PATHOLOGICAL INVESTIGATION ON THE CARCINOMA OF TH MAXILLARY SINUS (ESPECIALLY ON ITS PROGNOSIS)
}

Part 1: Clinical Observation on the Carcinoma of the Maxillary Sinus

Part 2: Pathological Investigation on the Prognosis and Histological Picture of the Carcinoma of the Maxillary Sinus

T. MOTAI

\author{
From the Department of Oto.Rhino-Laryngology, Nagoya University School \\ of Medicine (Director: Prof. S.Goto) \\ From the 2nd Department of Pathology, Nagoya University School of \\ Medicine (Director: Prof. H. Tauchi) \\ From the Department of Oto-Rhino-Laryngology, Nagoya City University \\ Medical Schoo! (Director: Prof. G. Matsuda)
}

One hundred and three surgical cases of carcinoma of the maxillary sinus, were examined and the following results were obtained through the clinical observation and the pathological investigation.

(1) Nasal obstruction, nasal hyperdischarge, dentalache and swelling of the cheek, etc. had been noticed as the initial symptoms, but those former three symptoms were not characteristic to this disease.

(2) As the type of cancer multiplication the so-called retro-growth type had been most frequently observed.

(3) Because of these two aforesaid facts, over $70 \%$ of the cases were not diagnosed correctly at the first examination.

(4) Consequently, the prognosis became unfavorable.

(5) No significant relationship was noticed between the histological diagnosis and the prognosis, however, a definite relation was found between the pleomorphism of cancer tissue and the prognosis.

(6) Prognosis was considered to be unfavorable in the cases which presented the varied histological pictures, especially so in those cases which presented these pictures due to Tauchi's socalled atypical adenocarcinoma.

(7) Some considerations were made on the histological picture of the parenchyma and the stroma as well as on the correlation between the two and a histological standard is presented by the author, for the purpose of grading the malignancy of cancer tissue.

As stated above, it may be concluded that, in order to make an early diagnosis and treatment possible, the attention must be paid to the atypical symptoms, and that both the pleomorphism of cancer tissue and the type of cancer growth have influence on the prognosis of the disease. 


\title{
上顎癌の臨床的観察並びに病理組織学的研究
}

\author{
（特に予後に関連して）
}

名古屋大学医学部耳鼻咽喉科学教室(指莩後藤修二教授)

名古屋大学医学部病理学教室第 2 满匪 (指導田内 久教授)

名古屋市立大学医学部耳鼠咽喉科学教空（指導松田新一教授）

$$
\text { 研究生 䳡 哲 也 }
$$

\section{第 1 編 臨 床的 観 察}

\begin{tabular}{|c|c|}
\hline 次 & 第 8 節 予後と性別 \\
\hline 緒＼cjkstart論 & 第 9 慨 予後と街式 \\
\hline 第 2 章 統計的観察 & 第 10 穊 予後之癌腫增殖籁国型 \\
\hline 第 1 節 統計 資 料 & 第 4 章 結 諭 \\
\hline 第2 節 傾度 & 献 \\
\hline 第 3 節 年次別頻度 & 第1章 緒 \\
\hline 第 4 節 年令及び性 & 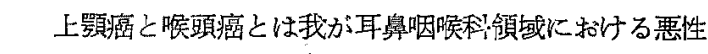 \\
\hline 第 5 節 患 側 & 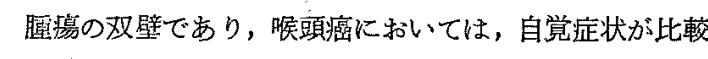 \\
\hline 第 6 節 原因並びK誘因的事项 & 的早期に現われる点並びにその発生部位的関係から, 早 \\
\hline 第 1 項 職 業 & 期影断・早期治療も比較的実施可能であり，從つて予後 \\
\hline 第 2 項 望伝的関係 & も比較的良好であるのに反し，上頭癌では癌䡋一般につ \\
\hline 第3愐 既往症として慢性副勆腔炎 & いての研究がかなり進んでいる現況に执いてもなる早期 \\
\hline 第 4 項 外力による刺戎 & 誩断・早期治療に関しては幾多の障壁が存在し, 従つて \\
\hline 第 7 節 症 状 & その予後む甚だ芳しくない現状である。 \\
\hline 第 1 項 初 発症状 & 著者はかる現状に鑑み，週去 13 力年間に名古屋大 \\
\hline 第 2 項 主訴 & 学並びに名古屋市立大学耳鼻咽喉科代来院した上顎癌患 \\
\hline 第 3 项 初骖診断名並びに初診時治療 & 者について，できうる限り，種タの観点より分析し，統 \\
\hline $\begin{array}{c}\text { 第 } 8 \text { 節 初発症状発現より初彭玉での期間と当科受 } \\
\text { 診までの期間の比較 }\end{array}$ & $\begin{array}{l}\text { 計的観察を行い，上顎癌の早期診断・早期治療について } \\
\text { の，拁り所を見出し，もつて治癒率向上に資したいと考 }\end{array}$ \\
\hline $\begin{array}{l}\text { 第 } 9 \text { 節 当科来院玉でに受けた外科的処置 } \\
\text { 第 } 10 \text { 節 リンパ節腫脤 }\end{array}$ & $\begin{aligned} \text { 光,本研究をこっろざしたのである. } \\
\text { 第 } 2 \text { 章 統計的観察 }\end{aligned}$ \\
\hline 第 11 節 手術所見より䂓た癌腫增殖籍团 & 第1節 統計資短 \\
\hline 第1項＼cjkstart癌腫增殖笨因型の分類 & 統計資䊅としては，上顎癌症例の内，明かに籍骨洞・ \\
\hline 第 2 項 癌腫增殖籁国型の䊧度 & 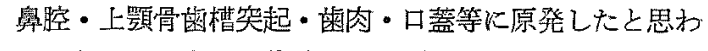 \\
\hline 第 12 節 痁腫の種類 & れるむのは，すべて除外し，上顎洞に原発したと思われ \\
\hline 第 3 章 予後に関する臨床的観察 & 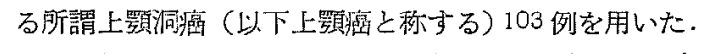 \\
\hline 第 1 節 術後死亡者並びに平均生存期間 & その内訳は, 昭和 21 年より同 29 年までの9 年間に, 名 \\
\hline 第 2 節 街後生存者並びに平均生存期間 & 古屋大学耳門咽喉利（以下名大臨床と称する）に入院し \\
\hline 第 3 節 無返信者の退院時状况 & たもの68 例，昭和 24 年上り同 33 年きでの 10 年間に, \\
\hline 第 4 節 再発部位と平均再発时㙋 & 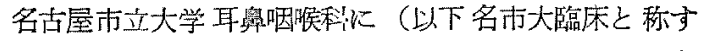 \\
\hline 第 5 節 遠隔 成 䌦 & る）人院したもの35 例である.な排手韧症例は，各 \\
\hline 第 6 節 予後の分類 & 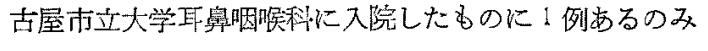 \\
\hline 第 7 節 予後と年令 & であとはすべて手術症例である。 \\
\hline
\end{tabular}


第 2 節 頻度

第1表に示す如く，

第 1 表 名大臨休及び名市大臨林にお ける上㽬痛の頻度

\begin{tabular}{|c|c|c|}
\hline 名大臨床 弨 $21 \sim 2$ & $9 n$ 年淔) 68 例 & 乔マに沜る比\% \\
\hline 外来患者総 数 & $370 / 4$ & 0.18 \\
\hline 入院患者総数 & 2749 & 2.47 \\
\hline 入院腫癌患者総敏 & 355 & 79.2 \\
\hline 入院㿋腫患者総教 & 251 & 27.7 \\
\hline
\end{tabular}

\begin{tabular}{|c|c|c|}
\hline 名市大臨床 昭24 & 加年间) 35 估 & 各マに対する比％ \\
\hline 外来患者総 数 & 42561 & 0.08 \\
\hline 入院患者総故 & 2008 & 7.74 \\
\hline 入院瘦腫患者総数 & 86 & 40.7 \\
\hline
\end{tabular}

\begin{tabular}{|c|c|c|}
\hline \multicolumn{2}{|c|}{ 耐大学臨朱昭 $21-33(13 n$ 年間) 103 例 } & 各々は対する比\% \\
\hline 外来患者総歌 & 79575 & 0.13 \\
\hline 入院患者緿敬 & 4757 & 2.17 \\
\hline 入院癌腫患者繶数 & 337 & 30.6 \\
\hline
\end{tabular}

第 2 表 上顎癌の频度

\begin{tabular}{|c|c|c|}
\hline \multicolumn{2}{|c|}{ 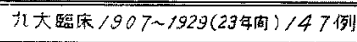 } & 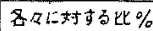 \\
\hline 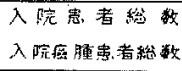 & $\begin{array}{r}72091 \\
578\end{array}$ & $\begin{array}{c}1.22 \\
25.4\end{array}$ \\
\hline
\end{tabular}

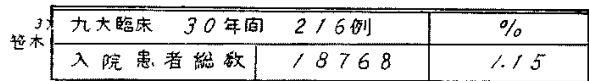

\begin{tabular}{|c|c|c|c|}
\hline$=1$ & 京大臨床 50 年菂 & 448例 & $\%$ \\
\hline U. 本 & 入院虫者出制 & 23450 & 7.91 \\
\hline
\end{tabular}

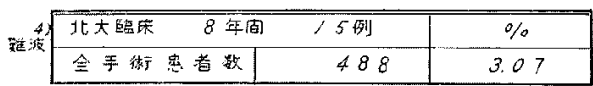

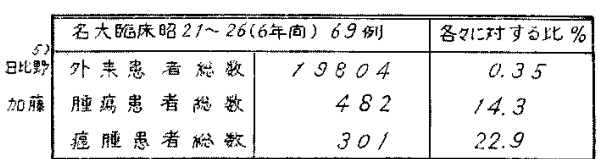

名大臨床では68例（837 例，931 例）で, 外来蝟者 棇数 37014 名の $0.18 \%$ ，入院患者総数 2749 多の $2.47 \%$ であり，悡市大亚床では35例（324例，911例）で

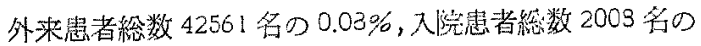
1.74\%である。闭臨床を通鼻すれば 103 例（る61 例，
第3表入院癌繮患者部位別分類

（）内は夫々総数（名大臨床 251 ，名市大臨床

86）に対する比\%

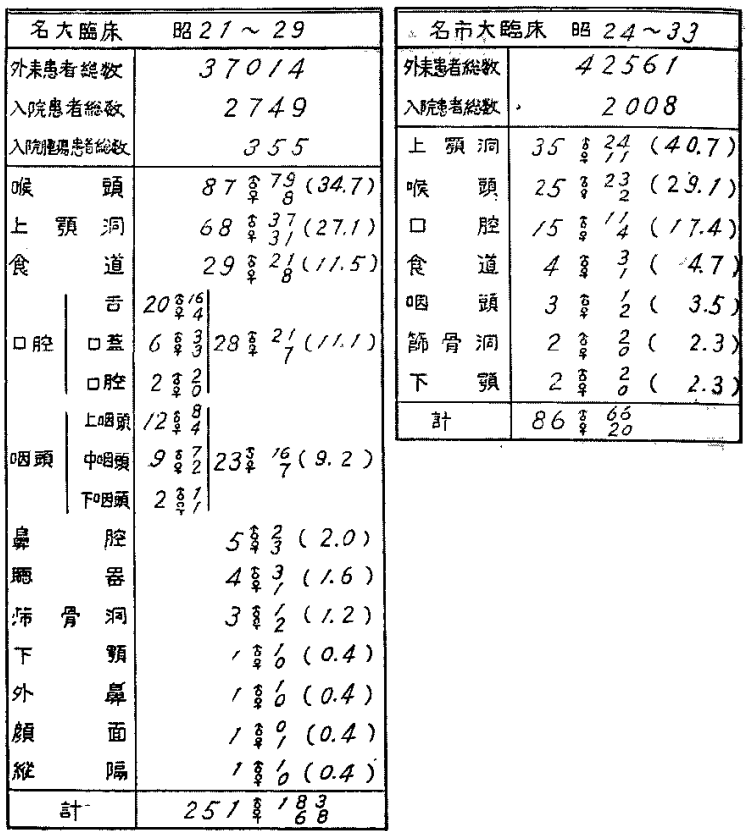

942 例) で，外来患者総数 79575 名の $0.13 \%$ ，入院患者 総数 4757 名の $2.17 \%$ ，又入院癌腫患者総数 337 名の 30.6 $\%$ に相当する.

諸家の報告と比較すれば，第 2 表の如くで，

入院患若総数に対する比では，著者の名大臨床（9年 間) $2.47 \%$ が最も多く次いで，京大臨床 1 (50 年間) の $1.91 \%$, 著者の名方大臨床 (10 年間) の $1.74 \%$,九大 臨床 2)(23 年間) の1.22\%，最も少ないが九大臨床 ${ }^{3)}$ (30 年間) の $1.15 \%$ である。

全癌霾患者数に刘する割合は，第3㐮の如くで，

名大䠦床仕 251 例中 68 例 $(27.1 \%)$, 名市大臨床で注 86 例中 35 例 (40.7\%) であり，いずれも堠頭癌と共に その頻度が高い。

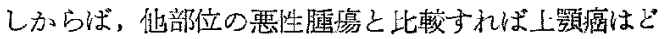

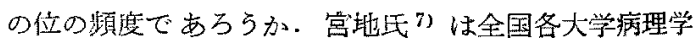

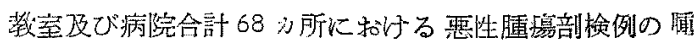

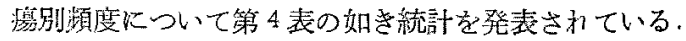

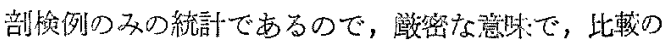

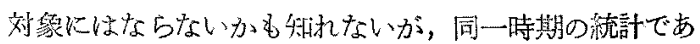

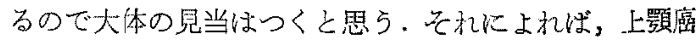
は，慗性湩湟剖検例総数 11927 例中 151 例 (1.3\%) であ 
第 4 表 全国各大学病理学教室及び病院合計 68 所に示ける覀性腫癖剖検例の腄 瘦別頻度（実数 100 例以下除外）

\begin{tabular}{|c|c|c|c|}
\hline \multicolumn{4}{|c|}{10 年間 (昭和 $2 /$ 年 230 年) } \\
\hline \multicolumn{3}{|c|}{ 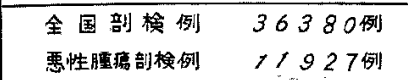 } & \multirow[b]{2}{*}{ 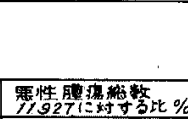 } \\
\hline 順 位 & 堙瘍名 & 实 数 & \\
\hline 1 & 㿋 & 2677 & 22.4 \\
\hline 2 & 白血病 & 1306 & 10.9 \\
\hline 3 & 肺 & 1033 & 8.7 \\
\hline 4 & 子宮庶 & $7 / 4$ & 6.0 \\
\hline 5 & 肝癌 & 639 & 5.4 \\
\hline 6 & 继覀性堙瘦 & 406 & 3.4 \\
\hline 7 & 㭔㴔 & 383 & 3.2 \\
\hline $8^{\circ}$ & 細細肉䐈 & 3.7 .3 & 3.1 \\
\hline 9 & 食道痤 & 372 & 3.7 \\
\hline 10 & 胆衰及び胆管痹 & 360 & 3.0 \\
\hline 11 & 㔀癌 & 269 & 2.3 \\
\hline 12 & 卵㧺 & 190 & 1.6 \\
\hline 13 & 大晹癌 & 189 & 1.6 \\
\hline 14 & 䗩 至 腫 & 180 & 7.5 \\
\hline 15 & 肾猫 & 172 & 2.4 \\
\hline 16 & 上襩洞瘦 & 151 & 1.3 \\
\hline 17 & 喁喉㾖 & 145 & $: 2$ \\
\hline 18 & リンパ肉檤 & 139 & 1.2 \\
\hline 19 & ホジキン戍新 & 124 & 1.0 \\
\hline 20 & 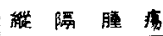 & $1 / 4$ & 1.0 \\
\hline
\end{tabular}

り，第16 位を占め，咽喉癌 145 例 (1.2\%) を瞱加に凌 いでいる。

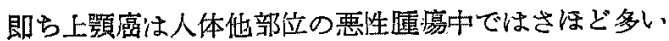
頻度ではなく，耳鼻咽猴利領域では，むしろ食道癌が第 9位で，上枵癌上り上位にあることになる。

\section{第3 節 年次別頻度}

癌死亡率生近年特见堌加の傾向にあると言われ，瀨木 6)・盗地7)は昭和 23 年より徐々に增加の傾向を巡りつ \あると述べている。

上硕癌に和いては，年次的增加はどのよらなるのであ ろらか，第 5,6 表に示す如く，画大学臨床とも，各年度

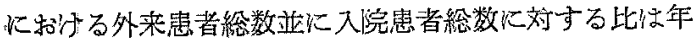
次の進むにつれ，要動しつ>も增加している. 殊に名大 臨床厄赫いては，昭和 21 年から23年までの3年間と， 昭和 24 年から 29 年をでの 6 年閶とる，名市大臨床に扰 いては，昭和 24 年から 26 年末での 3 年間と, 昭和 27

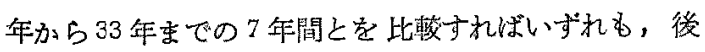
者の年間に和ける频度が高いことを知る・即ち上顎癌に
第 5 表 名大隐床

\begin{tabular}{|c|c|c|c|c|c|c|c|c|c|c|}
\hline 平虔 $(\overrightarrow{D N})$ & 21 & 22. & 23 & 24 & 25 & 26 & 27 & 28 & 29 & 竍 \\
\hline 外末巷者 & 2432 & 3093 & 3075 & 3299 & 3687 & 4452 & 5040 & 5881 & 6055 & 37014 \\
\hline 入院患吉好 & $2 ? 7$ & 206 & 210 & -374 & 261 & 300 & 360 & 405 & 406 & 2749 \\
\hline 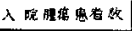 & 18 & 23 & 30 & 34 & 50 & 51 & 49 & 48 & 52 & .355 \\
\hline 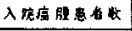 & 12 & 17 & 23 & 22 & 3.5 & 39 & 37 & 40 & 26 & 251 \\
\hline 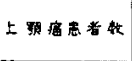 & $\begin{array}{ll} & 3 \\
3 & 1 \\
8 & 2\end{array}$ & $\begin{array}{l}5 \\
2 \\
8 \\
8\end{array}$ & $\begin{array}{r}82 \\
+\quad 92\end{array}$ & $8{ }_{84}^{54}$ & $\mid \begin{array}{r}5 \\
27 \\
95\end{array}$ & $\begin{array}{l}\$ 5 \\
\$ 4\end{array}$ & 554 & $15 \begin{array}{c}57 \\
98\end{array}$ & {$\left[\begin{array}{r}106 \\
94\end{array}\right.$} & $\begin{array}{r}837 \\
63 \\
93.31\end{array}$ \\
\hline 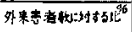 & 0.12 & .0 .06 & 0.13 & 0.24 & 0.33 & 0.20 & 0.10 & 0.26 & 0.17 & $0 . / 8$ \\
\hline 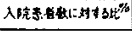 & 1.32 & 0.97 & 190 & 2.14 & 460 & 3,00 & 1.39 & 3.70 & 2.46 & 2.47 \\
\hline 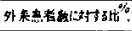 & 8500 & 要中 & 0.10 & & B414石中 & $\Phi 59 \%$ & 0.2 & & & \\
\hline 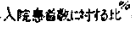 & 643 & & 4 예 640 & & 210580 & 中 59 \% & 2.80 & & & \\
\hline
\end{tabular}

第 6 表名市大踷床

\begin{tabular}{|c|c|c|c|c|c|c|c|c|c|c|c|}
\hline 每事 $(\overrightarrow{a x})$ & 24 & 25 & 26 & 27 & 28 & 29 & 30 & $3 \%$ & 32 & 33 & $\Delta+$ \\
\hline 丰奢呚 & 4456 & $39 \geqslant 1$ & 4377 & 4463 & 4172 & 4684 & 4205 & 4344 & 3970 & $39: 9$ & 42561 \\
\hline 综患番牧 & 132 & 143 & 230 & 259. & 184 & 270 & $2 / 3$ & 222 & 206 & 200 & 2008 \\
\hline 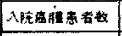 & 4 & & & $m$ & 12 & 14 & 12 & 8 & $a$ & 10 & 26 \\
\hline & $\begin{array}{l}81 \\
90 \\
\end{array}$ & 70 & $\begin{array}{ll} & 1 \\
9 & 0 \\
\end{array}$ & $\left|\begin{array}{ll}5 & 3 \\
4 & .\end{array}\right|$ & $\begin{array}{l}85 \\
70 \\
\end{array}$ & $\begin{array}{r}56 \\
50 \\
90\end{array}$ & $\begin{array}{r}53 \\
7.4 \\
\end{array}$ & \begin{tabular}{|c|c|}
5 & 2 \\
3 & 2 \\
7 & 1 \\
\end{tabular} & $\begin{array}{r}50 \\
292 \\
\end{array}$ & $\begin{array}{r}52 \\
583 \\
\end{array}$ & \\
\hline 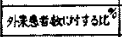 & 0.02 & 0.03 & 0.02 & 0.09 & 0.12 & 0.13 & 0.87 & $a^{o} 7$. & 0.05 & $a / 3$ & 0.08 \\
\hline 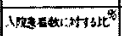 & 0.76 & 0.70 & \begin{tabular}{l|l}
0.43 \\
\end{tabular} & .54 & 2.72 & 2.86 & 3.29 & 1.35 & 0.97 & 2.39 & 474 \\
\hline 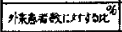 & \multicolumn{3}{|c|}{$12798849 \sin 0.02$} & \multicolumn{3}{|c|}{2976369.} & 32 但 & \multicolumn{3}{|l|}{0.11} & \\
\hline 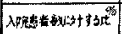 & \multicolumn{3}{|c|}{$505 \%$ 3910 0.59} & & \multicolumn{2}{|c|}{150384} & 324例 & 2.13 & & & \\
\hline
\end{tabular}

执いても，他癌價と同じく，近年增加の傾向にあること 加分る。

第 4 節 年全及び性

(第7 表) 最高は74才女子，最低は23才女子であり， 男子の最高は70才，最低は31才である，而して40才

第 7 表

(○オ〜19才には1例むない)

\begin{tabular}{|c|c|c|c|c|c|c|c|c|}
\hline \multicolumn{2}{|c|}{ 年 '令 } & \multicolumn{2}{|c|}{$\delta$} & \multicolumn{2}{|c|}{9} & \multicolumn{2}{|c|}{ 計 } & \multirow{2}{*}{ 1031: $4+33020 \%$} \\
\hline \multirow{3}{*}{$20 \sim 29$} & 5 & 0 & \multirow{3}{*}{0} & 1 & \multirow{3}{*}{2} & 1 & \multirow{3}{*}{2} & \\
\hline & 不 & 0 & & 1 & & 1 & & \multirow[t]{2}{*}{1.9} \\
\hline & 再 & 0 & & 0 & & $0^{\prime}$ & & \\
\hline \multirow{3}{*}{$30 \sim 39$} & 右 & 3 & \multirow{3}{*}{8} & 5 & \multirow{3}{*}{8} & 8 & \multirow{3}{*}{16} & \multirow{3}{*}{15.5} \\
\hline & 㾏 & 4 & & 3 & & $?$ & & \\
\hline & 両 & 7 & & 0 & & $l$ & & \\
\hline \multirow{3}{*}{$40 \sim 49$} & 吉 & 7 & \multirow{3}{*}{17} & 7 & \multirow{3}{*}{11} & 14 & \multirow{3}{*}{28} & \multirow{3}{*}{27.2} \\
\hline & 在 & 9 & & 4 & & 13 & & \\
\hline & 両 & 1 & & 0 & & 1 & & \\
\hline \multirow{3}{*}{$50 \sim 59$} & $t_{0}$ & 7 & \multirow{3}{*}{17.} & 3 & \multirow{3}{*}{9} & 10 & \multirow{3}{*}{26} & \multirow{3}{*}{25.2} \\
\hline & 호 & 9 & & 5 & & 34 & & \\
\hline & 両 & 1 & & 1 & & 2 & & \\
\hline \multirow{3}{*}{$60 \sim 69$} & 右 & 10 & \multirow{3}{*}{175} & 5 & \multirow{3}{*}{9} & 15 & \multirow{3}{*}{24} & \multirow{3}{*}{23.3} \\
\hline & t不 & 5 & & 4 & & 9 & & \\
\hline & 西 & 0 & & 0 & & 0 & & \\
\hline \multirow{3}{*}{700} & 右 & 3 & \multirow{3}{*}{4} & 2 & \multirow{3}{*}{3} & 5 & \multirow{3}{*}{7} & \\
\hline & 在 & 1 & & 1 & & 2 & & 6.8 \\
\hline & 两 & 0 & & 0 & & $o$ & & \\
\hline & E & 30 & & 23 & & 53 & & \\
\hline 計 & 媇 & 28 & $6 i$ & 18 & 42 & 46 & 103 & \\
\hline & 两 & 3 & & 1 & & 4 & & \\
\hline
\end{tabular}


第 8 表

\begin{tabular}{|c|c|c|c|c|c|c|c|c|}
\hline 報 壹 者 & $0 \sim 97$ & 10 拊 & $20 \pm \mathfrak{A T}$ & $20 \div$ & $40+x$ & 50 皮代 & 60N1t & 70 芹代 \\
\hline 京大熰床 ${ }^{3}$ & 0 & 2 & 8 & 23 & 37 & 50 & 39 & 7 \\
\hline 新鼬大䠄场 31 & 0 & 0 & 2 & 3 & 9 & 15 & 8 & 0. \\
\hline 九大囬朱 & 0 & ' & 8 & 34 & 59 & 63 & 32 & 8 \\
\hline 林 8) & t & 0 & 2 & 17 & 37 & 44 & 34 & 12 \\
\hline$\therefore \quad 9$, & 0 & 0 & 0 & 2 & 12 & 12 & 6 & 1 \\
\hline 保 & 0 & I & 3 & 16 & 4.3 & 47 & 30 & 7 \\
\hline
\end{tabular}

第 9 表

\begin{tabular}{|c|c|c|c|c|c|}
\hline 乹 & 告 & 㫮 & 男子 & 女子 & 男子：女子 \\
\hline 京 & 大 蹈 & 赫) & 105 & 61 & $172 \div 1$ \\
\hline$九$ & 大 的 & 皮 $^{3 \prime}$ & 134 & 71 & $1.89: 1$ \\
\hline 小 & 林 & 8) & 87 & 60 & $1.45: 1$ \\
\hline$山$ & 本 & 9) & 24 & 9 & $2.67: 1$ \\
\hline 久 & 保 & 2) & 107 & 40 & $2.68: /$ \\
\hline 浅 & \# & 10) & 82 & 53 & 1.55 \\
\hline
\end{tabular}

代に最も多く27.2\%，次いで50才代 $25.2 \%$ ，60才代 23.3 $\%$ の順で，40〜69 才の癌年令が綌数の 75.7\%を占めて いるのは今迄の諸統計（第8表）と余り大差がないが， ただ今迄の諸統計では 50 才代に最も多い点のみが異つ ている．この点より，癌年令が低下してきているのでは なかろらかと考えられる。

性別では男子61 例に刘し女子 42 例でその比は 1.45： 1である、諸家の統計（第9表）では，男子対女子の比 は最高が久保 2)氏の 2.68: 1, 最低が小朴8 の $1.45: 1$, 平均 1.87: 1であり,これと著者列とを比軹 寸れば男子が平均より少ないのは，女子の発症率が堌加 してきているのではなかるらか.しかしいずれの報告例 においても，男子に多いといら点では一致している。

第 5 節 患側

(第 7 表)：右側 53 例，左側 46 例で右側にや〉多く， 両側は 4例である.この「両側」とは, 両側上顎洞に癌 嗹が認められたといら意味であつて，両側同時に又無関 係に発生したという意味ではない，諸家の紌計（第 10 表）によれば，報告者により少数差乍ら逆の数値を示す むの屯あり，総体的には左右差はないむのっよ5であ

第 10 表

\begin{tabular}{|c|c|c|c|c|c|}
\hline 啹 告 & 者 & 右 㑡 & 左 側 & 両 & 侧 \\
\hline 新潟火虫 & 厓 9) & 21 & 16 & & \\
\hline 九 大 䠗 & 床 3 ) & 93 & 111 & & \\
\hline H & 本 9 & 13 & 18 & & 2 \\
\hline & 林 8 ) & 69 & 17 & & 1 \\
\hline
\end{tabular}

る.又両側に発生した例は，山本氏きの2 例，小朴氏日) の 1 例方市。.

第6 節 原因並びに唀因的事項

$$
\text { 第 I項 職緎 }
$$

(第 11 表)：無職が最も多く 38 例 (36.9\%) であり， その殆どが女子である. 次いで㟽業・漁業従事者が 24 例 $(23.3 \%)$ ，労働者が 20 例 $(19.4 \%)$ の順でありこれ らはその殆どが累子である.男子では労働者が男子総数 の $29.5 \%$ ，ついで農業漁業從事者が $26.2 \%$ と比較的加 重な仕事をしているすのに多いようである。

\section{第 11 表 職 掣}

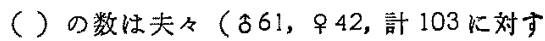
る比 (\%) である.

\begin{tabular}{|c|c|c|c|}
\hline 憕 & $\delta$ & ㅇ & 計 \\
\hline 的策能 & 8 & 30 & 38 \\
\hline 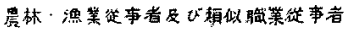 & & 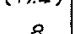 & 64 \\
\hline 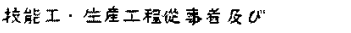 & $(26.2)$ & 0 & $(23.3)$ \\
\hline 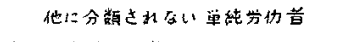 & $(29.5)$ & 2 & 20 \\
\hline 管理的蒀業徒事省 & 5 & r & 6 \\
\hline 事裙復事者 & 4 & 0 & 4 \\
\hline 段责從事者 & 2 & 0 & 2 \\
\hline サービス職羓從事者 & 2 & 0 & 2 \\
\hline 光 の 他 & 6 & 1 & $\dot{7}$ \\
\hline 計 & 67 & 42 & 10.3 \\
\hline
\end{tabular}

第 2 項 遗伝的関係

(第 12 表)：記載の明かな 101 例の内 18 例 [(17.8\%) に和いて，家系に癌属を認めた。内訳では父母に癌種が 認められたるの12 例で最も多く，ついで同胞の 4 例と なつている。諸家の統計では小朴氏 ${ }^{8)}$ は 147 例中 33 例 (22.4\%) に家采に素因を認め，飯田氏 ${ }^{11)} 36$ 例中6

第 12 表 遗伝的関係 (101 例中)

\begin{tabular}{|c|c|c|c|c|c|}
\hline 众系朝 & 鬲 & & 癌 & & 7 \\
\hline 手系祖 央 & 7 & 宮 & 癌 & & 1 \\
\hline 全 & 而 & & 㾇 & $7\}$ & 8 \\
\hline & 肺 & & 痹 & 11 & \\
\hline f & 胃 & & 㾇 & 31 & 4 \\
\hline म्य & 子 & 宮 & 痹 & , & 4 \\
\hline & 罥 & & 癌 & 31 & \\
\hline 同! 肥 & & 宮 & 㾇 & , & 4 \\
\hline 計 & & & & & 8 \\
\hline
\end{tabular}

例 $(16.7 \%)$ ，広戸氏 ${ }^{12)}$ は 137 例中 31 例 $(22.6 \%)$ ，水 野谷氏 ${ }^{13)}$ 世 19 例中 2 例 (10.5\%) に夫々遺伝的素忝を 認めている. 
第3 項 既往症として慢性副鼾腔炎

既往症としての慢性副鼻腔炎は，上顎癌発生に対乙関 係ありとするもの文なしとするものよ二者がある，広戸 氏 ${ }^{12)}$ は上簤 (副鼻腔) 癌腫 137 例中，蓄膿症の既往を 有するもの 27 例 $(19.7 \%)$ を認め，上顎蓄澧症が上顎 癌の発生に対し梁い関俰あるを察知されると述べてい るが，浅井氏 ${ }^{10)}$ は，副奥腔炎の既往症を有するすのは

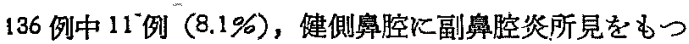
小のは 14 例 (10.3\%) であり，副鼻腔炎が腫漡に移行

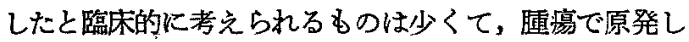
て片側性鼻炎副鼻腔炎で発症するるのが多いと述べてい、 る.その他諸家の報告に上れば，上顎癌患者の慢性副與 腔炎罪患率は，小林氏 ${ }^{8)}$ は 147 例中 45 例 $(30.6 \%)$ ，水 野谷氏 ${ }^{13)}$ は 19 例中 8 例 $(42.1 \%)$ ，山本氏 ${ }^{9)}$ 沬 33 例 中 12 例 $(36.4 \%)$ 等を報告している.

著者の観察では, 記載不備なるのを除いた 100 例中 23 例に漫性副鼻腔炎の既往を認めた・しかして,その内 3 例

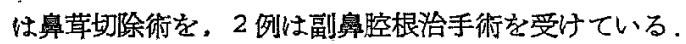
既往に副鼻腔根治手術を受けた 2 例は夫々 23 年後・ 30 年後に上頍澏に羅患している.

浅开氏 ${ }^{10)}$ は，'青少年期㨽鼻腔炎手術を受け，数年 10 数年後癌年令期仁至つて上顎癌をきたした例はなく， 経験した 5 例はずへて術後性頖部翼腫であり，青少年期 に特ける副奥腔根治手術を癌発生の面から考慮すへきで 票ると述べている。

著者の経験した 68 才男子の例では，右側の副鼻胵根 治手術を受けてから 26 年後に，反対側に上頴澏を発症 しており，か」る点から，副鼻腔根治手術は上顎癌発生 に必ずしも密接な関係があるとは言い切れない。

副鼻腔根治手術後飞上顎癌をきたした症例は小林氏 ${ }^{8)}$ は 3 例(発癌前 37 年・10 年・ 4 年), 吉川氏 ${ }^{8)}$ は 1 例を 報告しているがいずれもその原因については不明である と述べている.

第 4 項 外力に上る刺激

101 例中 3 例が 発癌側に外力に上る刺激を受けてい る. 即ら症例 1 は 43 才女子で 発癌前 5 年に右窂根部を 打撲し，右側発癌している。症例 2 は63 才男子で転 倒して左煩部を打撲 5 年後に 同側に 発癌している. 症 例 3 注 64 才男子で右煩部を強打 4 力月後に同側発癌 している：しかしこれの多では上顎癌発生に外傷が関係

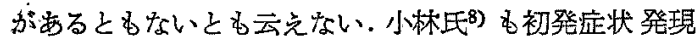
前の眼下部の打撲を誘因として訴えた2 例を報告し，恐 らく偶発事であるらと述べ，広戸氏 ${ }^{12)}$ は患部の外傷と 発癌との関係侩りないようであると述べている。

\section{第 7 節 㱏状}

第1項 初発症状

総症例数 103 中記載明かな 101 例について検討した。 (第 7節すべてに共通)

(第 13,14 表)：初発症状の最子 発現し易い部位は番 部で，次いで煩部・口腔の順となつている。即ち，番症 状で初発する場合が最も多くなつている，個々の定状 で言总ば，第14表仙示す如く，鼻閉が最も多く(19.8

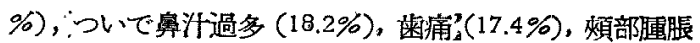

第 13 表

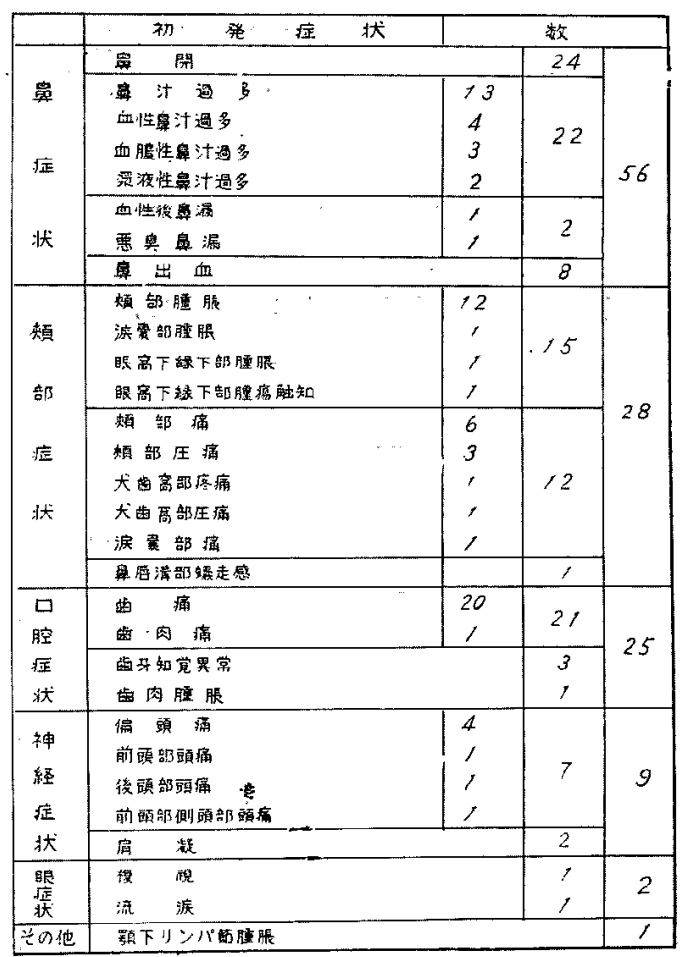

第 14 表

\begin{tabular}{|c|c|c|c|c|c|}
\hline 初 & 発 & 症 & 状 & 数 & $\begin{array}{l}\text { 唋数 } 121 \mathrm{~K} \\
\text { 对方比\% }\end{array}$ \\
\hline 奥 & & & 閉 & 24 & 19.8 \\
\hline 乘 & 沪 & 過 & 多 & 22 & 18.2 \\
\hline 歯 & & & 瘦 & 21 & 17.4 \\
\hline 類 & 部 & 腫 & 脹 & 15 & 12.4 \\
\hline 頉 & 部 & & 瘦 & 12 & 9.9 \\
\hline 率 & 出 & & 血 & 8 & 6.6 \\
\hline 頭 & 游 - 偏 & 嵒 頭 & 痛 & 7 & 5.8 \\
\hline$z$ & $\infty$ & & 他 & 12 & 9.9 \\
\hline
\end{tabular}


(12.4\%) の順であり，煩部腄脹は第 4 位である，從つ て、このような初発症状の現われる時期は，癌增殖が末 た上顎洞骨壁を侵蝕破壤するに至らない状態であること が多いのであろう．しかしてこのような時期に診断をつ け，治療をしてこそ早期獄断・早期治憭が行えたと始め て云劣るのであらうが，実際には余りにも晚期䛦断・晚 其治療であることが多い。これ一つには，患者の無理 解にもより，多くの場合所謂顕現期になつてから我々専 卧医を訪れているからであるう。

この事実は，次の主訴が如実に示している。な和，上 噥癌罪患側之反対側に慢性副鼻腔炎の所見を他覚的に見 出したずのは 93 例中 23 例 $(24.7 \%)$ であり，殆どの者

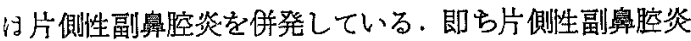
の症状や歯痛で初発するものが多い。

第 2 項 主 挀

(第15,16表)：主訴では煩部症状が最も多く次いで 皇症状となつている，個々の症状では，第16表の如く 煩部腷脹が 43.7\%で最も多く第1 位を゙占め，次いで鼻

\section{第 15 表}

\begin{tabular}{|c|c|c|c|c|}
\hline & 主 & & & \\
\hline \multirow{3}{*}{$\begin{array}{l}\text { 䫅 } \\
\text { 㰻 } \\
\text { 症 } \\
\text { 㧋 }\end{array}$} & 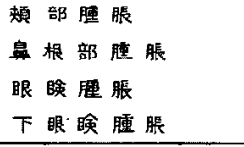 & $\begin{array}{r}50 \\
2 \\
1 \\
1 \\
\end{array}$ & 55 & \multirow[t]{3}{*}{68} \\
\hline & $\begin{array}{l}\text { 就 痛 } \\
\text { 煩部压痛 }\end{array}$ & $\begin{array}{r}11 \\
1\end{array}$ & 12 & \\
\hline & \multicolumn{2}{|l|}{ 项部知賞買常 } & 1 & \\
\hline \multirow{3}{*}{$\begin{array}{l}\text { 自 } \\
\text { 症 } \\
\text { 状 }\end{array}$} & 鼻閒 & & 21 & \multirow{3}{*}{37} \\
\hline & 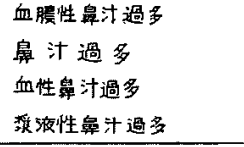 & $\begin{array}{l}5 \\
3 \\
1 \\
1\end{array}$ & 10 & \\
\hline & 稭 出 血 & & 6 & \\
\hline \multirow{3}{*}{$\begin{array}{l}\text { 口 } \\
\text { 胿 } \\
\text { 症 } \\
\text { 状 }\end{array}$} & 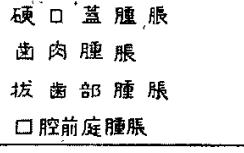 & $\begin{array}{l}4 \\
2 \\
2 \\
1\end{array}$ & 9 & \multirow{3}{*}{16} \\
\hline & 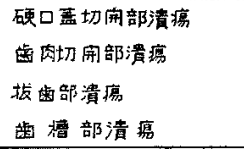 & $\begin{array}{l}2 \\
1 \\
1 \\
1\end{array}$ & -5 & \\
\hline & $\begin{array}{l}\text { 歯痛 } \\
\text { 硬口益㾑 } \\
\end{array}$ & , & 2 & \\
\hline $\begin{array}{l}\text { 良 } \\
\text { 搱 } \\
\text { 扰 }\end{array}$ & $\begin{array}{l}\text { 眼球突出 } \\
\text { 視力減退 }\end{array}$ & & $\begin{array}{l}2 \\
1 \\
\end{array}$ & 3 \\
\hline 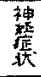 & 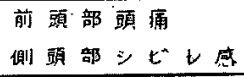 & & 1 & 2. \\
\hline
\end{tabular}

第 16 表

\begin{tabular}{|c|c|c|}
\hline 主 & 数 & $\begin{array}{l}\text { 総数 } 126 \mathrm{~K} \\
\text { 対する比\% } \\
\end{array}$ \\
\hline 類 部 腫 脤 & 55. & 43.7 \\
\hline 鼾 閣 & 21 & 16.7 \\
\hline 痛 & 12 & 9.5 \\
\hline 鼻 汒過多 & 10 & 7.9 \\
\hline 口蓋 - 歯肉腫脤 & 9 & 7.1 \\
\hline 鼻 出 血 & 6 & 4.8 \\
\hline 口蓋・䛧肉泚演 & 5 & $4.0^{\circ}$ \\
\hline$\xi \quad \infty \quad$ 他 & 8 & 6.3 \\
\hline
\end{tabular}

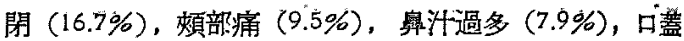
匊肉腫脹 (7.1\%) の順之なつている。

即ち，初登症状で1.2 位を占めていた鼻閉，鼻汁過多 は主訴では頻度が減じ，逆に初発症状で第 4 位を占めて いた頓部腫脹が主訴では第1 位となつている，又初発正 状では第 1 位の奥閉と第2 位以下とに頻度の開きが少な かつたのが，主語では第 1 位煩部腫脹と第 2 位番閉との 間にはその頻度にがなりの開きを見せている，従つてこ のような症状の現われる時斯は，とりもな就さず，癌䑏

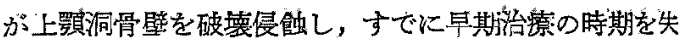
した状䉥であることが多いのであるう。

こへに上顠癌の治满率の低い原因の一つが存在する. 即占初発症状で第 1，2，3 位を占めていた鼻閉・番汁過多.

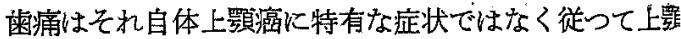
癌の非影現期の症状であると言えよう．そののために患者

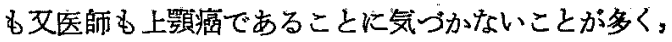

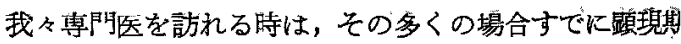
に入つてかららであることが明砝となつた。

しからば初発在状が発来してからどのような医療稀哭 訪れているのであららか。

第3項 初詮診断名並びに初猃時治療

(第 17 表)：初発症状が発来してか心最初に：約半楼 のものが鼻利医を訪れている。(101 例中 56 例 55.4\%)

残りの約半数が歯科医を訪れている（101 例中 28 伍 $27.7 \%)$ ．患者にしてみれば，初発症状から当然な成行 きであうう。しかし医師の側がら見た場合，果して当然 な成行きだと云党よらか。鼻利医を訪れた56 例中 24 侈 (42.9\%) が上颚癌と正しく診断されてb，32 例（56 任

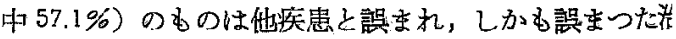

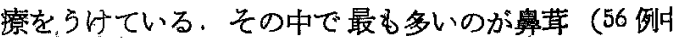
12 例 $21.4 \%$ ) でありすべて 鼻茸切除術考受けている. 次いで慢性副勫腔炎と診断されたものが 10 例（56 例 
第 17 表 初診診断名並びに初診時治療

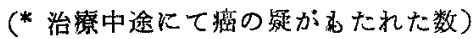

\begin{tabular}{|c|c|c|c|c|c|c|}
\hline 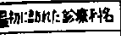 & 赔 & & 初韵输断名 & 弪 & 初烩時治癔 & $\dddot{x}$ \\
\hline \multirow[t]{2}{*}{ 鳥 } & 56 & $\begin{array}{l}\text { 以 } \\
\text { 外 } \\
29\end{array}$ & 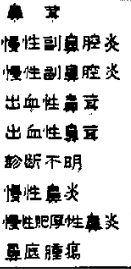 & $\begin{array}{r}12 \\
6 \\
4 \\
r \\
r \\
2 \\
y \\
r \\
y\end{array}$ & 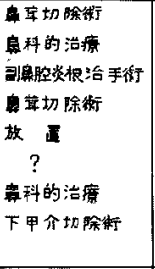 & $\begin{array}{l}4 \\
y \\
2 \\
1\end{array}$ \\
\hline & & $\begin{array}{l}\text { 当 } \\
\text { 科 } \\
27 \\
\end{array}$ & 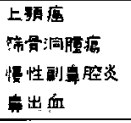 & $\begin{array}{r}24 \\
r \\
r \\
r\end{array}$ & & ', \\
\hline $\bar{F}$ & 28 & 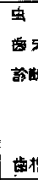 & 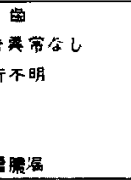 & $\begin{array}{l}17 \\
5 \\
3 \\
1 \\
1 \\
1\end{array}$ & 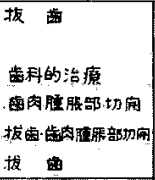 & 2 \\
\hline 内 & 17 & 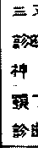 & 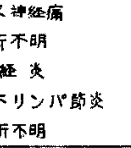 & $\begin{array}{l}5 \\
3 \\
1 \\
5 \\
1\end{array}$ & 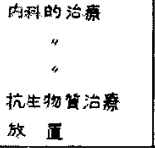 & 3 \\
\hline$\vec{F}$ & 4 & 㳂 & 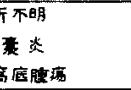 & $\begin{array}{l}2 \\
t \\
t\end{array}$ & 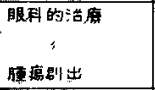 & 7 \\
\hline 病 & 2 & & 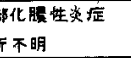 & i & $\begin{array}{c}\text { 抗生物算治瘞 } \\
? \\
?\end{array}$ & 1 \\
\hline 計 & 701 & & & & & \\
\hline
\end{tabular}

17.9\%)でその内4 例が副鼻腔根治手術を受けている.

歯利訪れたもの 28 例では匊牙火 異常なしと云われた 6のは 5 例 (28 例中 17.9\%) のみで 18 例（28例中 64.3 \%)のむのが抜歯を受けている、内科医を訪机たものは11 例 (101 例中 $10.9 \%$ ) で 3 例が誉断不明で 5 例（11 例中 45.5\%) が三叉神経痛と睃断されいずれる内科的治療を 受けている。

㕛治璙中途に癌らしいと分つたるのは全科を通じて 19 例市了。即ら総应例数 101 例中 24 例 (23.8\%) が初 診時に上顎癌と䛦断をつけられ，77 例 (76.2\%) のもの

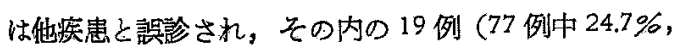
101 例中 18.8\%)のものが中途から癌と判つたような現 状であり，いかに多くのものが早期治潦の時期を失して いたかがよく分る。

第 8節 初発症状発現より初䜌までの期間之当科爱 影までの期間の比較

初発店状発現して最初から当利:を訪孔るものは第 17 表に示す如く 27 例 (101 例中 $26.7 \%$ ) あ勺残りの74 例 (101 例中 73.3\%) のおのは他の医滰穖関を最初から訪
第 18 表初発症状発現より初彰亡での期間 と初登症状発現より当科受部主で の期間

（*）は初めから当科受䩕したもの了数

\begin{tabular}{|c|c|c|c|c|c|}
\hline \multicolumn{3}{|c|}{ 初発症状登現よリ初彭まで } & \multicolumn{3}{|c|}{ 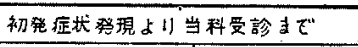 } \\
\hline 数 & 期 & & 閤 & 数 & (*) \\
\hline 66 & & - & /カ月来満 & 14 & (5) \\
\hline 12 & ノカ月以上 & $\sim$ & З力月未渾 & 23 & (5) \\
\hline 10 & 3力月以上 & $\sim$ & 5力月末满 & 26 & (8) \\
\hline 2 & 5力月以上 & $\sim$ & 7カ月来满 & 16 & (2) \\
\hline 3 & 7 力以上 & $\sim$ & 9 力月米䓄 & 8 & (3) \\
\hline 0 & 9 力月以上 & $\sim$ & ケカ年末满 & 1 & \\
\hline 2 & ノカ年以上 & $\sim$ & 3カ年末满 & 7 & (7) \\
\hline 6 & 3力年以上 & $\sim$ & & 6 & (3) \\
\hline $10 \%$ & $\longleftarrow$ & 訳 & $\rightarrow$ & 101 & (27) \\
\hline
\end{tabular}

れている。しからばとの時期的の開きはどよらなる のであろらか，第 18 表に示す如く66 例（101 例中65.3” \%) のあのは初発症状が発来してから1刀月以内に何等 加医察機関を訪れている，しかし当利を訪れる時期は

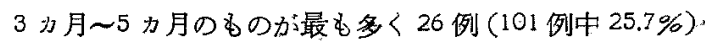
となつている.その間には2 2 月〜4力月の開きがあり， この開きが前述の如き初発症状と主訴との差となつて現 われ，しかして上買洞癌であるべきすが顔面頭蓋癌と あ云らべき様相を呈し専門医の前に現われてくることに なる.

第 9 節 当科来院までに受けた外利的观置 第 7 節第 3 項で，他の医療㙨関であるいは鼾革切除術 あるいは拔霜等ィを受け，その後に当科を来訪している あのがあることが分つたが，これらはいずれる初科医 （最初に訪れた医療機関．以下これに準ずる。）に颃いて 受けたものである。しかし初科医以後当科京訪れるまで の間に，種々の外科的如置を受けているものもある。

第 19 表に示す如く，初秘医では何も外科的処置を受 けず，その後当科家訪れるまでの間に外科的观置を受け たものが23 例 (62 例中 37.1\%), 初科医でも受け，次の 医寮機関でも受けたもの即占再手術例が7例（62 例中 11.3\%)，初利医だけで受けたもの39 例 (62 例 62.9\%)で あり全手術例数では69例となる. 即ち総症例数 101 例 中62 例 (61.4\%) 加当科学訪れる以前に何処か心医療. 機関で，何等かの外科的奶置を受けていることになり， その頻度の大なるに鳘かされるのである。

外积的処置では拔蔝 21 例 (62 例中 $33.9 \%$ ) が最も多

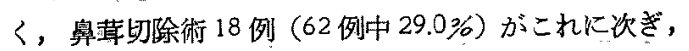
副鼻腔根治手衍は10 例（62 例中 16.1\%）である，総庭. 
第 19 表 当科来院までに受けた外科的処置

(馀查切除・診榅切開は除外してある)

\begin{tabular}{|c|c|c|c|c|c|c|c|}
\hline \multirow{3}{*}{ 手唃 名 } & \multirow{3}{*}{ 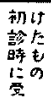 } & \multirow{2}{*}{\multicolumn{2}{|c|}{ 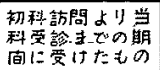 }} & \multicolumn{4}{|c|}{ 計 } \\
\hline & & & & \multirow{2}{*}{ 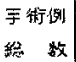 } & \multirow{2}{*}{ 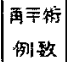 } & \multicolumn{2}{|c|}{ 症 例 数 } \\
\hline & & 再重衔 & 始めて & & & & $\%$ \\
\hline 类 & 18 & 2 & 3 & 23 & 2 & 27 & 33.9 \\
\hline 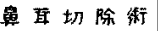 & 13 & 4 & 5 & 22 & 4 & 18 & 29.0 \\
\hline 副量腔根治手衡 & 4 & $o$ & 6 & 10 & $o$ & 10 & 16. \\
\hline 西肉·硬口䇺切荓 & 2 & 1 & 5 & 8 & I & 7 & 11.3 \\
\hline 顔 面 切用 & 0. & 0 & 2 & 2 & $o$ & 2 & 3.2 \\
\hline 上䫑洞穿籼 & 0 & 0 & 2 & 2 & 0 & 2 & 3.2 \\
\hline 下甲介 切除衡 & 1 & 0 & 0 & I & 0 & 1 & \\
\hline 眼害店 腫癌剔出 & 1 & 0 & 0 & ' & 0 & r & 1.6 \\
\hline 計 一 & 39 & 7 & 23 & 69 & 7 & 62 & \\
\hline
\end{tabular}

例数 101 例に対する比は夫々 $20.8 \% ， 17.8 \% ， 9.9 \%$ て ある。

第 10 節 リンバ節腫脹

臨床上，所属 リンパ節の腫脤を 触知し得たものは 97 例中 27 例 $(27.8 \%)$ である、諸家の報告によれば小林 氏 ${ }^{8)}$ は 147 例中 68 例に所属 リンバ節腫脹をみ，その中

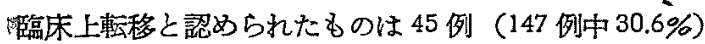
を算している. 浅井氏 ${ }^{10)} 136$ 例中 25 例 (18.4\%) K

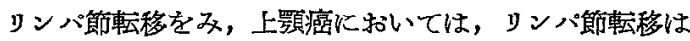
少く、リンパ節のみの再発も少いものであるから「局所

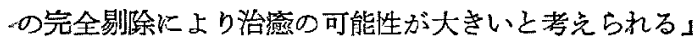
と述へている。

第 11 節 手術所見より観た滰腫增殖範囲

第 1 項 癌婳增殖範囲型の分類

上顎癌の抎がりを論ずる前に，癌腄の増殖部位あるい は方向による癌尰堌殖範囲型と侵蝕部位の名称を規定す る必要がある。ます諸家の報告をみてみよう。

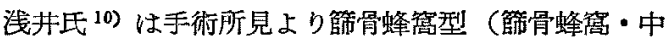

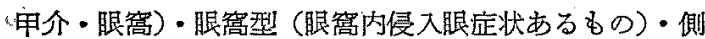
上顎型（翼状窝・頝骨・側頭窝）・下上顎型 (口蓋) - 後 上顎型（翼状突起・蝶形骨・上咽頭）・上上顎型（側頭

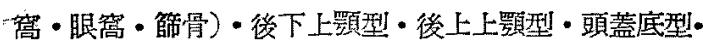

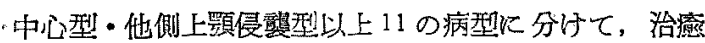

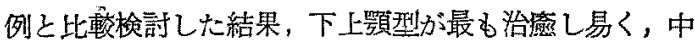
心型・侧上顎型がこれにつぎ，上上頡型・後上顎型では 治䟿成績が不良であると述べている。

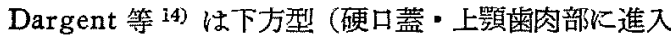
したもの)・前方型（上䫁前壁の方に進入したるの）・上 方型 (上顎洞眠營型 - 節骨上顎洞型) - 後方型 (翼口蓋简 轧進入する8の)・全面型（前後，上下，内外に向い進
入したもの）に分けて，治療の 結果と比較検討してい る.

㕛山本氏 9) は病変最る高度と 推定される部位を 鼻側

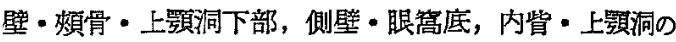
多方面儿膨隆するもの・篩骨・節骨, 眼简底・鼻底・不 明の9つの部分に分け予後との関係をみ，鼻側壁山経過 良好で，眼窩底，内㫮あるいは上嘪洞の多方面に膨隆す るものは不良のむの多く，飾骨に関するものは一般に不 良であつたと述べている。

以上主だたものであるがその他师）多くの学者が種 タに分類している。

ひるがえつて寒際の手術時の状況をみれば翼口蓋窩・ 翼状突起附近に侵蝕をきたしたるのは完全剔除が困難で あり，上顎洞側頭下面の前下部に侵飿をきたしたものは 剔除にさほど困難を感じないのは，我くの焦々経験する 所である. 又側頭下面の後部にある上顠結節は，骨がう すく癌睡增殖により侵蝕され易いのは事実である.

そこで著者は上述諸学者の分類や上頟洞の解剖学的特 徵や，手術時所見の事実を参考にし，上顎洞側頭下面を 額面断に扎いて前部と後部とに分けた方が妥当と考光， 上顎洞をかこむ骨壁を次のように嫢定した。

上 壁：上顎骨体の眼窝平面

内 壁：上頸骨体の鼻面

前 壁：上顎骨体の前面と上顮骨前頭突起

下 壁：上㖽骨口蓋突起

外側壁：上㖽骨体の側頭下面において，上㖽結 節の前縁より前部並びと上顎骨の歯槽 突起と暊骨突起

後 壁：上顎骨体の側頭下面に颃いて，上䁲結 節を含める後部

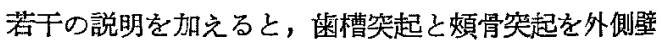
に加えたのは，著者の取り扱つた症例では，米槽塋起が 侵蝕される場合は殆どの場合小目歯崡槽より後部にみら れたので，歯槽突起への侵蝕は，多くの場合上顎骨体前 面にそくする部位は除外してさしつかえないと考皇たか らであり，煩骨突起もそれが侵蝕をうける際は上顎骨体 前面より侵蝕を受ける場合もあるが，多くの場合上顠骨 体側頭下面（ある場合注腿䆟壁から）の方から煩骨突起 の裹側に执いて侵蝕されるからである。

後壁とは上顎骨体側頭下面において上顎結節を含めて 後部の部分を云い丁度翼口蓋窩・翼状突起・下眼藷裂に 相詨している部分である。

しかして夫々の壁への侵蝕型式を，どの壁に执いて病 
変が最む高度であるかあるいはどの壁の方向へ侵蝕しっ ১あるか汇よつて上方型・内方型・前方型・下方型・外 側方型・後方型に分け以上 6 型式に侵蝕度合が甚ナ゙高度 でずれの進展方向に重点を执いてよいか不明のるのを

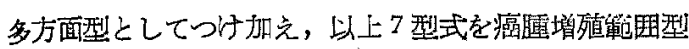
として分類した：

第 2 項 癌腫增殖鞍囲型の頻度

手術所見より病変が最も高度と思われる部位を判定 し，第 1 項で規定した 7 型式により分類した。総定例数 103 例中記載不備等を除外した 98 例についてみると第 20 表の如くであり，後方型が最も多く 98 例中 24 例(24.5 \%) 前方型が最も少く98 例中 7 例 (7.1\%) である. 又

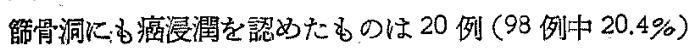
にみとめられ，後方型に多くみられた。

即古翼状突起 - 翼口蓋窝 - 翼状突起筋等手術操作上甚

第 20 表 癌隀增殖箱四型

（）は箁骬洞にも癌腄浸潤のあるもの 了例数

\begin{tabular}{|c|c|c|c|c|}
\hline 後 & 方 & 型 & $24(12)$ & $24.5 \%$ \\
\hline 多 & 方 面 & 型 & 18 (4) & 18.4 \\
\hline 上 & 方 & 㤠 & $17 \quad(4)$ & 17.3 \\
\hline 队 & 方 & 型 & 12 & 12.3 \\
\hline 外 & 側 方 & 型 & 11 & 11.2 \\
\hline$F$ & 万 & 堽 & 9 & 9.2 \\
\hline 前 & 方 & 䍿 & 7 & 7.1 \\
\hline & 計 & & $98(20)$ & 100.0 \\
\hline
\end{tabular}

だ厄介な部位への侵触が最も多かつたことは予後の上に 重大な意義を与えると云克るし，灭この部位へ侵触した 場合の手術操作に特別の考慮が払われなければならない 亡考克られ，今後の検討に残された問題点の一つである， 5 .

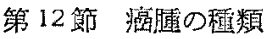

記載の明かな78 例中表皮癌 58 例 (74.4\%)，単純癌: 15 例 (19.2\%), 紡錘形細胞癌 4 例 (5.1\%), 腺癌 1 例. (1.3\%)であって表皮癌が最も多い。

\section{第 3 章 予後に関する臨床的観察}

第 1 節 術後死亡者並びに平均生存期間

昭和 34 年 9 月 12 日現在の状況を交書比よつて問合せ た結果で惊，総数 100 例中，死亡例 53 例，生存例 10 例， 返信なし37 例である。

死亡例 53 例の内訳は第 21 表に示す如くであり，上顎 癌組繶残存若しくは再発によりて死亡したものが殆でを 占め 40 例 $(75.5 \%)$ である.

術後合併应に上る死亡例が 3 例声り，総手術例数 102 例 (総症例数 103 例中非手術例は 1 例のみである)の 2.9. \%に相当する. 即ら手術危険率は $2.9 \%$ である.

表中 $\mathrm{B}, \mathrm{C}, \mathrm{D}$ は上影癌が直接死因にはなり得ない: 上橰癌が直接死因となり得るものは $\mathrm{E} ， \mathrm{~F}$ の合計 42 例： である.

この 42 例について術後生存期間を調查すると第 22 表 の如くである。な打期間年月数の算定は，部查潤放術等

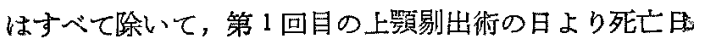
に至るまでの期間を算定した。

第 21 表 死亡 侧 53 例 の 内 訳

（）性存期間；放射線潦法開始若しくは第 1 回目の上顎剔出術の日上り 死しに至るまでの期間
A 非手注例（放射線療法）
(4力月 17 日)
B 術後合併定に上る死亡例

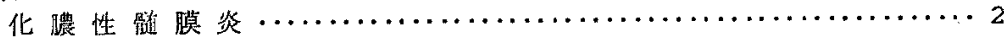
朕栓
塞
C 倗発性事由による死亡例

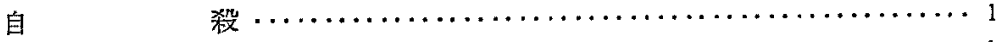
胢硕唯・脾 臛
D上顎癌再発によらない死亡例

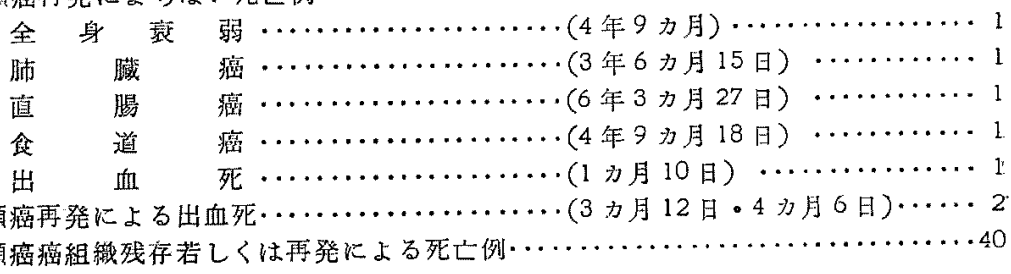


第 22 表 術後死亡者の徒後生存期間

平约生存期間： 8 力月

（昭和 34 年9月12日現在）

\begin{tabular}{|c|c|c|c|c|}
\hline 籍 後 & 生 存 期 南 & 例 & & 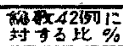 \\
\hline & 〜 2力月末满 & 0 & \multirow{5}{*}{72} & \multirow{5}{*}{28.6} \\
\hline 2 力以上 & 〜 3力月未族 & 2 & & \\
\hline $3 n$ 月以上 & 〜 4力月末満 & 2 & & \\
\hline 4 力月以上 & 一. 5 力月末満 & 5 & & \\
\hline 5力月以上 & $\sim 6$ 力月未満 & 3 & & \\
\hline 6力月以上 & 〜 フカ月末满 & 7 & \multirow{6}{*}{27} & \multirow{6}{*}{64.3} \\
\hline Tカ月以上 & ～8カ月未㴖 & 3 & & \\
\hline 8力月以上 & 〜 9 月末满 & 3 & & \\
\hline 9力月以上 & 〜 10力月末莎 & 6 & & \\
\hline 10力月以上 & 〜 川カ月末满 & 2 & & \\
\hline 17 月以上. & 〜 ノカ年末满 & 6 & & \\
\hline /カ年以上 & 〜 1.5 力年末满 & 2 & & \\
\hline 15 力年以上 & 〜 2力年未泟 & 1 & 3 & 7.1 \\
\hline 2 年以上 & $\sim$ & 0 & & \\
\hline
\end{tabular}

術後生存期間が 2 力月未満又は 2 力年以上の死亡者は 例もなく，42 例中 27 例 $(64.3 \%)$ の屯のが術後 6 カ 月から 1 カ年に至るむでの間に死亡し, 12 例 (28.6\%) が 2 カ月から6 月月至るむでの間に死亡，平均生存期 間は 8 力月と甚た短かい。

第 2 節 術後生存者並びに平均生存期間

第 23 表にみられる通り僅か 10 例であり，術後 1 度も 再発を認めなかつた例が 6 例あり，4 例は術後再発を 1 度はきたしているが，現在全く異常ない，最も期間の長 いむのは 8 年 7 カ月 6 日である.それらの平均生存期間 は 4.2 カ年である。しかしてこいは現在日常労㗢にい そしんでいるるのばかりである。

第 23 表 術後生存者 10 例の術後生存期間 第1回目の上频剔出術の日より昭和 34 年 9 月 12 日に至るまでの期間：

平均生存期問： 4.2 力年

\begin{tabular}{|c|c|c|}
\hline 症 例 & 㣝後生存期间 & 衡後経调概要 (再 発) \\
\hline$t$ & I年2 2 月 24 日 & \\
\hline 2 & /年3力月 28 日 & \\
\hline 3 & 1 年10力月 & 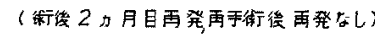 \\
\hline 4 & 3年7カ月/3日 & \\
\hline 5 & 4 年 18 日 & \\
\hline 6 & 4 年3 月 24 日 & ( 術㖟25日目再発 \\
\hline 7 & 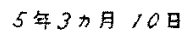 & \\
\hline 8 & 5 年/1月月 25 日 & 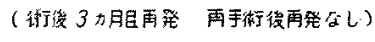 \\
\hline 9 & 6 年7カ月 $28 \mathrm{E}$ & \\
\hline 10 & 8 年7月月 6 日 & (街微3 月自再発 \\
\hline
\end{tabular}

第 3 節 無返信者の退院時状況

現在の状沿は全く不明であるが，退㹸時の状況を調査

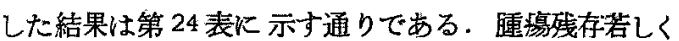
は再発を認めつ」退院したものが19例あり，これらに

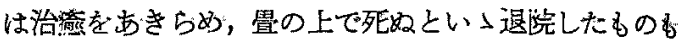
あり又治漝費がなくなりして退院した方のるある悲惨な 例であり，いずれも6力月末满に退浣しているが，第 1 䬣で述べた術後死亡者の平均生存斯間 8 引月と云ら事实 と退完時状況とにより，い寸゙れは死亡する準死亡者とみ なし得るむのぱかりである。

術後一度は再発したが遈院時には再発を認めなかつた むの3 例は，入院期间 1 カ年以上のむのばからであるの で，それらの経過と，術後死亡者の平均生存期留 8 力 並びに後述の平均再発時斯 2 力月といら事実より，生存 可能者とみなし得る. 又術後一度も再発を認めす経過し

第 24 表 無返信者 37 例の泿院時状況 (昭和 34 年 9 月 12 日現在)

1 術後一度も再発を認め一経過したも の15 例の内訳

\begin{tabular}{|c|c|c|c|c|}
\hline 入 & 澌 & 間 & 例 & 数 \\
\hline \multicolumn{3}{|c|}{2 カ月夈満 } & & 10 \\
\hline \multicolumn{3}{|c|}{2 力 以上 3 月月末満 } & & 3 \\
\hline \multicolumn{3}{|c|}{6 力月 27 日 } & & 1 \\
\hline \multicolumn{3}{|c|}{3 年 2 力月 } & & 1 \\
\hline
\end{tabular}

II術後一度は再発したが退院時には再 発を認めなかつたもの3例の内訳

\begin{tabular}{|c|c|c|c|c|c|c|}
\hline 症 & 例 & 入 & 院 & 期 & & 間 \\
\hline & & 1 年 & 1 カ & 月 & 20 & 日 \\
\hline & & 1 年 & 6 カ & 月 & 18 & 日 \\
\hline & & 2 年 & 28 & & & \\
\hline
\end{tabular}

III腫瘍残存若しくは再発を認めつろ 退院したもの19 例の内訳

\begin{tabular}{|c|c|c|c|c|}
\hline 入 & 院＼cjkstart期 & 間 & 例 & 数 \\
\hline & $\sim 1 s$ & 未泚 & & 2 \\
\hline 1 力月 & 以上 $\sim 2 引$ & 未满 & & 3 \\
\hline 2 力月 & 以上 $3 \rightarrow$ & 未満 & & 7 \\
\hline 3 力月 & 以上 $4 \%$ & 末渵 & & 3 \\
\hline 4 力月 & 以上 $\sim 5 \Rightarrow$ & 末満 & & 1 \\
\hline 5 力月 & 以上 $\sim 6$ 力 & 未满 & & 3 \\
\hline 6 少月 & 以上〜 & & & 0 \\
\hline
\end{tabular}


たもの15例は，後述（第 5 節）の如く，入院期間 3 年 2カ月のるのは準生存者とみなし得るが残りの 14 の例 もの〉予後怯全く不明である.

第 4 節 再発部位之平均再発恃期:

経過穓察中に再発を 全く認めなかつた泟例は99 例中

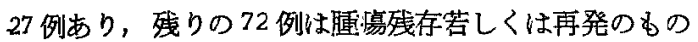
である．そこで明か腫場残存と思学るものは除外し牫 りの 62 例とついて，再発部位と再発期間とを調查した。 その結果は第 25 表の如くである.

第 25 表 再発部位と平均再発時期

\begin{tabular}{|c|c|c|}
\hline 王 部 位 $(62$ 㾏例 $)$ & 数 & 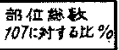 \\
\hline 眼高下新 & 26 & 24.3 \\
\hline 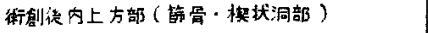 & 13 & 72.2 \\
\hline 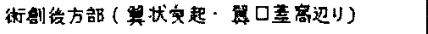 & 12 & 17.2 \\
\hline 頑部度店 & 12 & 11.2 \\
\hline 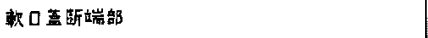 & 10 & 9.4 \\
\hline 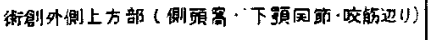 & 7 & 6.5 \\
\hline 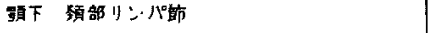 & 6 & 5.6 \\
\hline 㟽骨断踹 部 & 5 & 4.7 \\
\hline 上咽頭铹壁（耳管南口都） & 4 & 3.7 \\
\hline 硬口真斯蛅暗 & 3 & 2.8 \\
\hline 眼䆚内 & 3 & 2.8 \\
\hline 頭玉骨 & 3 & 2.8 \\
\hline 音根部 & 2 & 1.9 \\
\hline 确媵膜 & $y$ & 0.9 \\
\hline 発時 & & \\
\hline 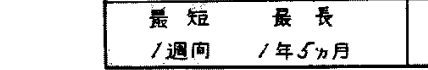 & $\begin{array}{l}\text { 平均 } \\
2 \text { 力月 } \\
\end{array}$ & \\
\hline
\end{tabular}

な和同 1 人でも， 2 力所以上に再発を認めたものは， 夫ィの部位へ 1 例ずっつけ加えた。

眼简下部へ再発したるのが最む多く，再発部位総数 107 例中 26 例 $(24.3 \%)$ である。，再発時期法最短術後! 週間, 最長 1 年 5 力月, 平约再発時斯は術後 2 力月であ る.

従つて術後 1 度も再発なく1年 6 カ月を経過すれば，

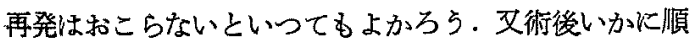
調に再発なく経過しても1年6カ月を経過するまでは， 再発に対し充分な注意を払い，郝後の監視を意らないこ とが必要であるう。

第 5 節 遠隔成結

第 1 節から第 4 節玉で〉，術後再発すべきるのは平均 2 力月，術後死亡すべきすの红平均 8 力月，生存し得る あのは平均 4.2 カ年ということが分つた．但し生存者の 平均生存期間は昭和 34 年 9 月 12 日までの值であり，以
後の年月がたつにつれ增加する管である．

この事笑から無返信者を整理してみよう。

第 3 節で述べた如く，腫場残存若しくは再発を認めつ 入退院したもの19例仙潗死亡者とみなしてもさしつか えなく，又術後 1 度も再発を認好ず退院したるの 15 例中 1 例は 3 年 2 刃月経過し生存者の平均生存期間 4.2 カ年に近いので準生存者とみなし得るが，14例のもの は㱠で 2 打以内に退院しているので，平均再発時期 2 力，平均死亡時期 8 力 月といら事觅上り，これら 14 例のむのは予後てついては全く不明である.

従つて記載不偳 3 例 - 非手衡例 1 例 ・ 上述 14 例, 合 計 18 例は術後遠隔成繢の対象からは除外することが必 要であり，総店例数 103 例から18 例を差引いた85 例に ついて術後治窬率を調查した．従つて各年間の手術例数 からるこの 18 例相当するすのがさしひいてある。

な和昭和 33 年度手術洌数は，9月以降手術したもの は1例のみで，そ机も術後 4 力月目に死亡しているの で、虺蟫成䑶の調查には妨げにならない

第 26 表 術後遠隔成續（術後治獜菜）

（昭和 34 - 年 9 月 12 日現在）

\begin{tabular}{|c|c|c|c|c|}
\hline & $\begin{array}{r}1 \text { 年以上 } \\
\text { 昭和 } 21 \text { 年 } \\
\sim 33 \text { 年 } \\
\end{array}$ & $\begin{array}{r}3 \text { 年以上 } \\
\text { 昭和 } 21 \text { 年 } \\
\sim 31 \text { 年 } \\
\end{array}$ & $\begin{array}{r}5 \text { 年以上 } \\
\text { 昭和 } 21 \text { 年 } \\
\sim 29 \text { 年 } \\
\end{array}$ & $\begin{array}{r}6 \text { 年以上 } \\
\text { 昭和 } 21 \text { 年 } \\
\sim 28 \text { 年 } \\
\end{array}$ \\
\hline 手術 例 数 & 85 & 78 & 68 & 55 \\
\hline 生存者 数 & $2 \mathrm{l}$ & 12 & 5 & 3 \\
\hline 治 㴔 率 & $24.7 \%$ & $15.4 \%$ & $7.4 \%$ & $5.5 \%$ \\
\hline
\end{tabular}

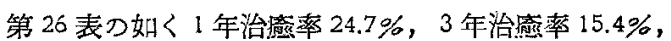
5 年治癒率 $7.4 \%, 6$ 年治率率 $5.5 \%$ である.

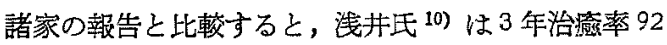
例中 23 例 $(25.0 \%) ， 5$ 年治凃率 62 例中 12 例 (19.4\%)

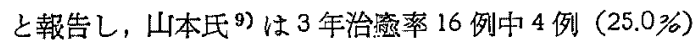
6 年治澰率 8 例中 2 例 $(25.0 \%)$ と報告している。これ らに比すれば芳ばしいものとは云えない甚だ残念な事东 である.

\section{第6 節 予後の分類}

死亡者 53 例中非手術死亡例 1 例，衐後合併应文以偶 発事由以よる死亡例 5 例，上買癌再発に上らない死亡例 中の出血死 1 例，第 5 節で述べた 14 例，婄載不硧 3 例 合計 24 例は上顎癌の予啳としては不明であるので，総 例数 103 例から，差到いた79 例について，前述の如き

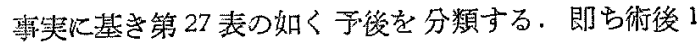

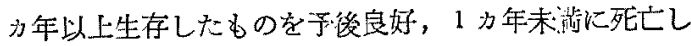


たもの老予後不良として分類すると，予後良好は 21 例 (79例中 $26.6 \%$ ），予後不皇は 58 例（79 例中 73.4\%）で ある.以下各項について予後との関係観察してみる。

第 27 表 予 後 9 分 類

\begin{tabular}{|c|c|c|c|}
\hline 予 後 & 術後生存撕間 & 例 数 & $\begin{array}{l}\text { 総数 } 79 \text { 例に刘 } \\
9 る \text { 比\% }\end{array}$ \\
\hline 好 & 1 力捨以上 & 21 & 26.6 \\
\hline 不 & 1 年沫㳢 & 58 & 73.4 \\
\hline
\end{tabular}

第7節 子後上年令

第 28 表の如く，高年者・登年者・年者の順に予後 が悪くなる傾向をみとめる．即占高年者に私いて子後が 良い傾河をみとめる。

第 28 表予後 と年 合

\begin{tabular}{|c|c|c|c|c|}
\hline 梅 & 合 & 例数 $(\%)$ & $\begin{array}{r}\text { 于掼良好 } \\
(\%)\end{array}$ & 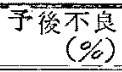 \\
\hline 若年者 & $\begin{array}{r}20 \text { 才代〜 } \\
30 \text { 才代 }\end{array}$ & $12(15.2)$ & $4(33.3)$ & $8(66.7)$ \\
\hline 中年者 & $\begin{array}{r}40 \text { 扎代 } \\
50 \text { 才代 }\end{array}$ & $44(5.5 .7)$ & $9(20.5)$ & $35(79.5)$ \\
\hline 高年者 & $\begin{array}{r}60 才 \text { 才代 } \\
70 \text { 才代 }\end{array}$ & $23(29.1)$ & $8(34.8)$ & $15(65.2)$ \\
\hline
\end{tabular}

第 8 節 予後と性別

第29表の如く，罗性は83\%が予後不良であるのに比 し，女性恬59\%が不良である。即ら女性に叔てて予後 が良い傾问をみとめる。

第 29 表予 後 と 性 別

\begin{tabular}{|c|c|c|c|c|}
\hline 性 別 & 例数 & $(\%)$ & 予後底好 $(\%)$ & 予後不良 (\%) \\
\hline $\mathcal{\delta}$ & 47 & $(59.5)$ & $(17.0)$ & $(83.0)$ \\
\hline 우 & 32 & $(40.5)$ & $13(40.6)$ & $19 \quad(59.4)$ \\
\hline
\end{tabular}

第9節 㞪後上術式

こ১ではどの術式が 有効適切であるが問題にしな い. 何故ならこのことは癌價堌殖籍圈のいかんによつて

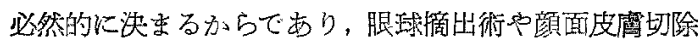
術を行らようではすでに㹸期治療というような状態の手 術であり，このような手術を行わなければならないもの は大多数に执、て子後不良であるのは第30表に見る如 くである。たら゙1例のみが予後が良好で文る。

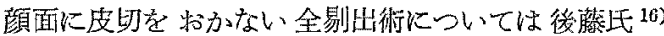
34) 等が精しい荐察を述べられているのてこつにはられ ないが，か〉る䌡口的全剔出術なむくまで癌堙全剔を第
第 30 表 予 後

*は口监粘膜を残したもの（全剔出術の際） (各 1 例)

\begin{tabular}{|c|c|c|c|c|c|c|c|c|c|}
\hline 街 & 玕 & 例教 & $8 \%$ & & 守彼 & 良好( & & & $\frac{\pi}{2}(\%)$ \\
\hline & Weber Ex & 401 & & & 9 & & & $3 i$ & \\
\hline & 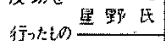 & 5: & 46 & 62 & 7 & 10 & & 4 & 36 \\
\hline 全影出衝 & Moure ז & 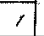 & & 02 & 0 & & 74 & 1 & 48 \\
\hline & 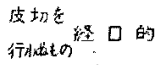 & & 16 & & & $4^{x}$ & & & $2^{(77 A)}$ \\
\hline 部分剔 & 街 & & 3616 & & & $(46)$. & & 7 & (53.8) \\
\hline 全剧出伡 & 厂干眼球摘出衡 & & $2(2$ & & & co & & & $(100.0)$ \\
\hline 全剔出体 & 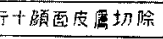 & & $6 \%$ & & & $(100.0$ & & & $(0)$ \\
\hline 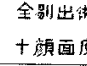 & 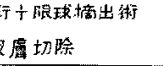 & & $(1)$ & & & 10 & & & $(100.0)$ \\
\hline & 註 & 79 & & & 27 & & & 58 & \\
\hline
\end{tabular}

一義上するのは当然であり，徒らに容琓上の点を第一義 としてはならないのは云うまでむないことである。即ち 顔面に皮切をおかなくとも充分全剔出術ができるいら 見通しをつけてから行らべきであり，従つでの適示に 充分意を厸らことが必要であるう。

第 10 節 予後と癌茞增殖範国型!

手術所見記載不備の 4 例を除外した 75 例について観

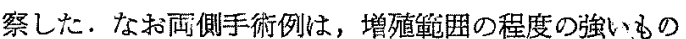
に重点を和いた。これは増殖範围が広ければそれたけ予 後に影響する所大なるものがあると孝えたからである。

第 31 表 予谽之癌腫增殖籁囲型

（）は簛骨洞にも癌朠浸潤のあるもの了数

\begin{tabular}{|c|c|c|c|c|c|c|c|c|}
\hline \multicolumn{3}{|c|}{ 癌腫堌要知曲型 } & \multicolumn{2}{|c|}{ 例啟 $[\%]$} & \multicolumn{2}{|c|}{ 予後良好 $[\%]$} & \multicolumn{2}{|c|}{ 子復不良 $[\%]$} \\
\hline & 方 & & \multicolumn{2}{|c|}{$2 /(10)[28.0]$} & \multicolumn{2}{|c|}{$2(2)\lfloor 9.5\rfloor$} & \multicolumn{2}{|c|}{$19(8)[90.5]$} \\
\hline & 方面 & & \multicolumn{2}{|c|}{$13(2)\lfloor 7.3\rfloor$} & & {$[7.7]$} & \multicolumn{2}{|c|}{$12(2)[92.3]$} \\
\hline 上 & t & 型 & \multicolumn{2}{|c|}{$\operatorname{rog}(x)\lfloor/ 3.3\rfloor$} & & {$\left[\begin{array}{ll}1 & 0\end{array}\right]$} & \multicolumn{2}{|c|}{$10(1)[100.0]$} \\
\hline 外 & 传 方 & 型 & 9 & $\lfloor 2.0\rfloor$ & 2 & {$[22.2]$} & $\cdot 7$ & {$[7760]$} \\
\hline 内 & 万 & 型 & 8 & $\lfloor(10.7\rfloor$ & 5 & {$[62.5]$} & 3 & 37.5 \\
\hline$T$ & $\hbar$ & 型 & 7 & $\lfloor 9.3\rfloor$ & 5 & {$[7 / 4]$} & 2 & {$[28.6]$} \\
\hline 前 & $\hbar$ & 型 & & [9.3] & 5 & {$[7 / 4]$} & 2 & {$[28.6]$} \\
\hline \multicolumn{3}{|c|}{ 計 } & \multicolumn{2}{|c|}{$75(13)$} & \multicolumn{2}{|c|}{$20(2)$} & \multicolumn{2}{|c|}{$55(11)$} \\
\hline
\end{tabular}

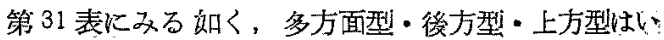

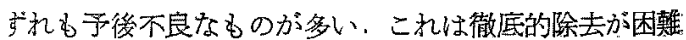

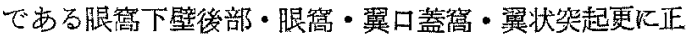
円孔・翼状突起箭等に浸溜している增殖型である故であ 万弓。

即古予後不良群 55 例中 41 例 $(74.5 \%$ ) が上記三型の 6のである。これに反し内方型・下方型・前方型はいず れも予後良好なものが多い，即ら良好群 20 例中 15 例 （75.0\%）を占めている．又外側方型は予後不良なる。 
ぷ多くなつている。

\section{第 4 章 結 論}

（1）本臨床的観察は昭和 21 年より同 29 年に至る9 年間に名古屋大学耳鼻咽喉利に入院した上頻洞澏悡者 68 名，並びに昭和 24 年より同 33 年まで至る 10 力年

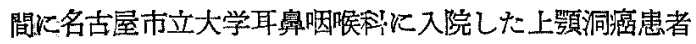
35名；合計103名について行つたものである，な特非 手術例は名古屋市立大学化入院したものに1 例あるのみ であとはすべて手術症例である。

（2）両臨床を 通算すれば，全癌腫患者総数 337 例の $30.6 \%$ の頻度である，又外来患者総数 29575 名の 0.13 \%，入院患者総数 4757 名の $2.17 \%$ に相当する.

（3）年次頻度では近年增加の傾向を認める。

(4)，年令的に 40 才上り 69 才迄の者唯 $75.7 \%$ を占的， 40 才代に最む多く，最高は 74 才女子で,最低は 23 才女 子である。今迄の緒統計では 50 才に最も多く，この点 より，癌年令の低下か゚考えられる。

（5）男子 61 例住対し女子 42 例で男子にや小多い，諸 家の報告例に括いても，男于に多くなつている。

（6）右側 53 例，左側 46 例，两側は 4 例であり，右側 虹や与多い，乙か乙統計を参照す机ば，総体的には左右 差はないるの〉ょうである。

(7) 職業では，無瞕の女子が最も多く，(103 例中 30 例 $29.1 \%$ )，男子に和いては学衝者 18 例（103 例中 17.5 $\%$ ）農業漁業従事者 16 例（103 例中 $15.5 \%$ ）等比較的 加重な仕事をしているものに多い

（8）101例中 18 例 $(17.8 \%)$ に遺伝的関係を認め，父 母癌䭪を認めたもの12 例が最も多い

（9） 100 例中 23 例飞慢性副鼾腔炎の既往を認るる.

(10) 上顎癌䍜患側之反対側に，慢性副鼻腔炎の 所見 を他覚的に見出したものは93 例中 23 例 (24.7\%) であ り，殆どの者は片側性副鼻腔焱艾併発している。

（11）鼻症状で初発するものが最も多く，個々の症状

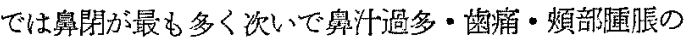
順である．この鼻閉・鼻渐過多・米痛は上顎癌に特有な 症状ではなく，上顎渻の非顕現期の症状であり，かつる 時期北診断をつけることがのぞましい，従って，癌年令

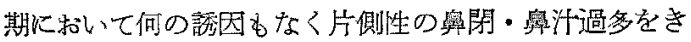
たした場合や，何の誘因むなく歯痛をきたした場合は先 ず上頸癌を念頭と打き精查すべきである。

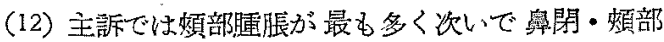
痛・鼻汗過多の順だある，即も顕現期に入ってから尃閴 医を訪れるものが多い。
（13）101 例中 24 例が初診時に上顎癌と診断がついて

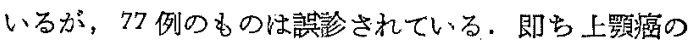

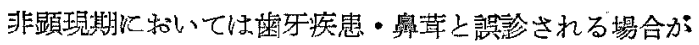
多い.

（14）初発症状発来してから何等かの医潆機関を訪机 るまでの期間は 1 力月未满の者が多く，初発症状発来し てから当臨床を訪れるまでの期間は 3 カ月以上 5 カ月未 满の者が多い。しかしてこの差が，初発症状と主訴の差 となつて現われ又上顗洞癌であるべきものが顔面顕蓋癌 ともいうべき様相を呈し塜門医を訪れる原因にもなり， 一般人の上顎癌に対する認識をたかめるよう辟蒙するこ とが必要である。

（15）当臨床を訪れるをでに，62 例（101 例中 61.4\%） が何等かの外稿的処置を受けている。

外稕的边置では拔类 21 例（62 例中 $33.9 \%$ ) が最も多 く，奥苜切除術18 例(62 例中 29.0\%). がこれに次ざ， 副鼻腔根治手術は 10 例（62 例中16.1\%) である.

（16） 97 例中 27 例 $(27.8 \%)$ に所属 リンハ節の缰脹を 触知する。

(17）癌腫增殖範用型を上方型・内方型・前方型・下 方型・外側方型・後方型・多方面型の 7 型式に分類寸る のが妥当である。

（18）後方型が最も多く98 例中 24 例 (24.5\%)，前方 型が最も少なく 98 例中 7 例 (7.1\%) である. 穊骨洞に る癌婳浸潤を認めたものは 20 例（98 例中 20.4\%）であ

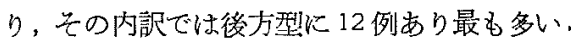

（19） 78 例中表皮癌 58 例 - 单純澏 15 例 - 紡鉭形細胞 癌 4 例・腺癌 1 例であり，表皮癌が最も多い。

（20）手術危俟率は $2.9 \%$ である.

（21）術後死亡者 42 例中 27 例 (64.3\%) のものは， 術後 6 力月から 1 力年に至る亲での間に死亡し，12 例 (28.6\%) のるのは 2 カ月から6カ月に至るまでの間に 死亡している. しかして術後死亡者の平均生存期間は 8 カ月である。

(22) 昭和 34 年 9 月 12 日現在に打ける術衡生存者の 平均生存期間は 4.2 力年である。

（23）術後再発部位は眼筒下部が最も多く，再発時期 は最短, 術後 1 週閏, 最長, 術後 1 年 5 力月, 平均再発 時期性術後 2 力月である. 従つて術後 1 年 6 力月を経過

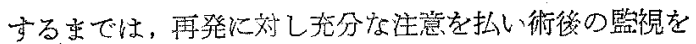
㥐らないことが必要である。

（24） 85 例の 遠隔成斜では 1 年治痖率 $24.7 \% ， 3$ 年治

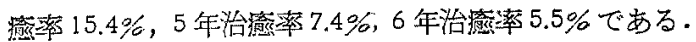


（25）術後 I刀年以上生存したものを予後良好，1力 年末満に死亡したものを予後不良として，分類すると， 予後良好は $26.6 \%$ (79 例中 21 例)，予後不良は $73.4 \%$ (79 例中 58 例) である。

（26）高年者に执いて 予後が良い傾向を認め，中年者 に和いて予後が悪い傾向を認める。

(27) 女性に和いて予後が良い傾向を認める。

(28) 後方型・多方面型・上方型・外側方型はいずれ 予後が不良のものが多く, 内方型・下方型・前方型は いずれる予後が良好なるのが多い。

\section{主要文献}

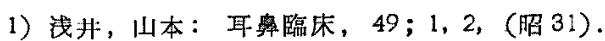

久保: 臨床耳鼻咽喉科学, 20 頁, 克誠堂畫店発行, (昭 15). 3) 䈎木：日本耳奥咽喉科全書, 第 2 卷, 4 册, 䛗床編备渝 四，244頁，(昭 30).4）難波：3上り引 用.5) 日比野, 加藤：現代医学，3；2，39，(昭 28). 耳娚臨床，46；11，772（昭 28）. 6) 瀨木：田辺= בース，209 号，8頁，(昭 30). 7) 宮地：日本医師 会雑誌， $41 ； 2$, (昭 34). 8) 小林: 淁医誌, $67 ; 2$, 311 , (昭 27). 9) 屾本：日耳睤，49；11，53，(昭 18). 10) 浅井：日耳鼻，61; 臨時号，379，(昭 33). 11) 飯田: 耳舆臨床, 40；2６，1，(昭 22). 12) 広 戸：耳與臨床， $40 ； 2 \sim 6,6$, (昭 22). 15) 水野谷：

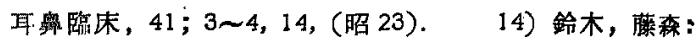
耳奥咽喉科最近の進步，467頁，医雪葉出版発行，(昭 31). 15) Dargent: 14 上り引用. 16) 後藤 (修): 線合臨床，1；5，452，(昭 27)，17）後藤 (修)：手 術： $4 ; 8,320$, (昭 25). 18) 本庶：医学：9;3， 120，(昭 25)，19）後藤（光）：外科の領域， $4 ； 6$ ， 365, (昭 31)，20）浅井，藤岡：耳鼻㰓床，46；12，

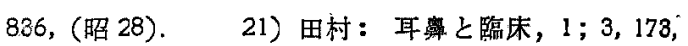

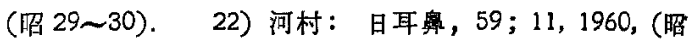
31). 23) 岡田：東京医事誌，3000咢，2617 頁（昭 11). 24) 後藤（修）：日耳鬼，55；7,562（昭 27）。 25）後藤（修）：日耳舆，56；8，679，(昭 28）。 26） 浅井：日本耳鼻咽喉科全書，第 5 巻， 2 冊，鼻科禍，80 頁（昭 28）. 27）今川：日本耳鼻咽喉科全書; 第 3 巻，1 冊，口腔，259 頁，(昭 28). 28）遠藤：口腔 外科通論及び手術学，205 頁，歯科学報社発行，(昭 17)。 29）尾崎：日耳鼻，42；5，678，(昭 11).30）Francis Lederer: Diseases of the Ear, Nose and Throat； p. 432, (1944). 31) 前田, 西端: 耳鼻臨床, $51 ; 3,1$, (昭 33). 32) 久保, 茰, 中山：癌の臨床, $3 ; 5,659$ ，(昭 32). 33）浅井（昭）：日耳奥，60； 10，1408（昭 32). 34) 河田：手術，4；6，225（昭 25).

第 2 編予後に関する病理組織学的研究

\begin{tabular}{|c|c|}
\hline & 次 \\
\hline 第 1 章 緒 & 諭 \\
\hline \multicolumn{2}{|c|}{ 第 2 章 検悹材料及び検等方法 } \\
\hline \multicolumn{2}{|c|}{ 第 1 節 検䒜材糊 } \\
\hline \multicolumn{2}{|c|}{ 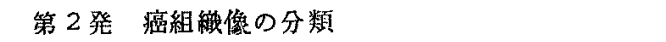 } \\
\hline \multicolumn{2}{|c|}{ 第 3 節 予後の分類 } \\
\hline \multicolumn{2}{|c|}{ 第 4 節 成鼠の榆討 } \\
\hline \multicolumn{2}{|c|}{ 第3章 検 案成 縓 } \\
\hline \multicolumn{2}{|c|}{ 第 1 節 組繶学的診断と予後 } \\
\hline \multicolumn{2}{|c|}{ 第 2 節 癌組紨構成と予後 } \\
\hline \multicolumn{2}{|c|}{ 第 3 節 実䓄並びに間質に和ける諸形態学的態度と } \\
\hline \multicolumn{2}{|r|}{ 予後 } \\
\hline \multicolumn{2}{|c|}{ （1）解放像の有無と予後 } \\
\hline \multicolumn{2}{|c|}{ (2) 間岳発育の程麻と予後 } \\
\hline \multicolumn{2}{|c|}{ (3) 間留反応の程度と予後 } \\
\hline \multicolumn{2}{|c|}{ (4)間留の血管発育の程度と予後 } \\
\hline (5) 癌 & 察細胞配列の規即性の程度と予後 \\
\hline
\end{tabular}

(6) 多型像の程度と予後

(7) 核分剖像の頻度と予後

(8) 過染性核出現の頻度と予後

(9) 角化度の程度と予後

(10) その他の所見と予後

第 4章 総括並びに考按

第 1 節 㴦腫組織像と予後に関する文献的考察

第 2 節 組絨学的診断之予後

第 3 節 澏組織满成と予後

第 4 節 実質並びに間質における諸形態学的態度を 予後

第 5 節 悪性度判定基集

第 5 章 結 諭
文 献
付图説明

第1章 緒論

上顎癌の組職学的研究, あるいは組䋨学的所見と予後 


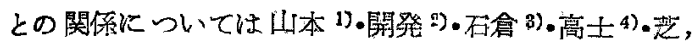
久島，馬埸ら) 氏等の詳細な确究がある。

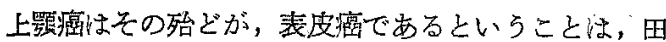
中7), 篗木 ${ }^{8)}$ 氏等多数12)3４）の学者の一致して述べて いる所である。しかし乍ら組織像と予後との関係に関し

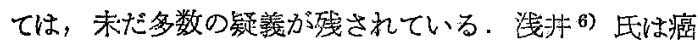

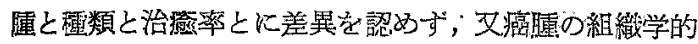
覀性度と予後との間にも明確な差異を認奶ないと述へ， 吉田氏 ${ }^{14)}$ は悪性度決定に心組織学的所見を砳と乙，臨 床所見を主として行らことが適切であると述べ，留発 2 氏は上顎癌に特ける厥平上皮癌について，Haagensen 氏分類法及び Greenough 氏分類法深用いて覀性度判 定を行う時には，充分な考慮が必要であると述べてい る. 又山本 1) 氏は上噥癌の予娞の渗定は，組織学的所見 のみによることは不可能であり，臨床所見にも左右され ることは勿論であると述べ, 組織学的所見と䠦床所見の 雨者を加味した悪性度判定基準を立てついる。

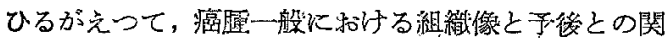
保沉ついての研究は枚挙にいとまないが，大体次の3い の傾向に大別することができるそその14古く1897年 v. Hansemann の Anaplasie の概念の提唱より端を発 し A.C. Broders (1920) を経て現在侄つている所の， 実質細胞の Anaplasie の程度上り予後を推察しょうと い弓傾向.

その 2 は, Mac Carty (1922) の提唱した, 間筫にお ける变化を 重視する傾向で，即ち 問筫に 円形細胞浸潤 や，結合織の線維化乃至硝子化が著明火現われている程 度の強い程，予後が良好であり，これらの変化を癌細胞 の発育比対する，防御的の組織反応（防御的因子 defensive factors）とみなするのである。その3は癌細 胞增殖段階と間貿之を構築学的な立場から見る今井 12)， 所 ${ }^{17)}$ 氏等の傾向であり，今井氏は予後は，踟塊辺縁部 (発育先端部) 飞猢る，実質と間質との，相対関係に 左右されるむので，この部位の所見が重要であると述べ ている.

上述 3つの傾向のうち，その 2 の Mac Carty の防御

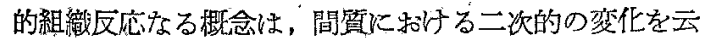
タしているのに過ぎないと否定され，その10 Broders の分類法については，緒方の 氐は組織学的の Anaplasie の程度は，帮性度とある点までは一致するが，これ にはかなり多数の例外を認めた上のことであると述べ， 岩本 13)，氏は喉頭癌 160 例飞ついて観察し，術後の再発 と関係があることが楒められたが，著明ではなかつたと 述へ，更に癌蕾の予後判定上密接な関保を有する脈管内
蒙延像が，Broders 氏分類法では無視されている点に筑 点があると論じている．その他後藤，浅井，三吉 ${ }^{10)}$ 。

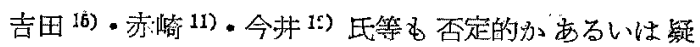

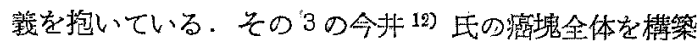
学的な立場から見る傾问について性，之の後多くの追試 者が，氏の提唱する簊出の程度・CPL 分類等により予

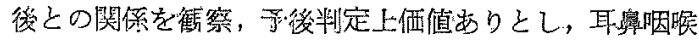

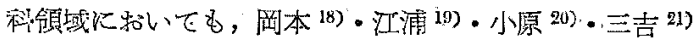

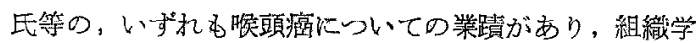

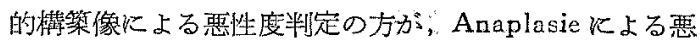
性度判定上りも，予後を推定する上红合理的かつ禺際的

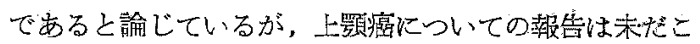
れを見ず，合朴氏の構築学的分類法がずでての場合飞あ ては出るか否かには、な和疑義が残されている。

さて上颚癌の現状は，臨床的镍察で述べた如く，その 殆どが，早期の手術例でなく，剔出の際，大小種々の癌 熄片として剔出されることが多く，従って復元む困難で ある、殊に今井氏の癌塊構築の立場より検討する際に は，前述の如く奏質之問筧の相互関傒が重要であるか， 部位的に盖異省すことが少くなく，従つて大なる切片

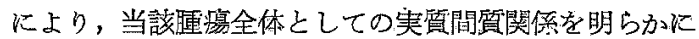
するこどが必要であつて，今井氏はか子る検索の目的を

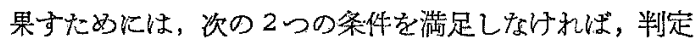
が困難であると注意されている。

。即方

（1）癌塊の中心点を通り，その発去方向に可及的平行 の断面を作り，しかも当該癌塊の江緑乃至周围組織を充 分含めた全割摽本（あるい性可及的これ沉近いもの）を 作ること。

（2）先亓虫鏡的弱摭大に上つて充分観察乙 histotopographische Orientierung をつけること.

しかし，本材料のように剔出された大小種会の癌塊片 に対して，この忞件を充たすことは凡そ不可能である。

一方，一般的江癌望の組織搆成は，癌細胞の多様な形 態・間貿の多彩な態度・癌細胞と間質との多相な関連性 に加うるに，癌細胞本来の特徵としての止も所を知らな

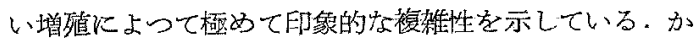

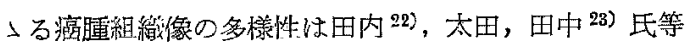
多数の学者によつて, 指㒀されている所であり, 副番腔 癌に恬いても，高土 ${ }^{4)}$ 氏 態学的多様性を指摘し，か人方点上り，純形態学的分類 をなすことは，むしろ無意味であつて，その腰揚構造変 異の法則性と限界を知ることがより本質的であると述べ 
ている.

そこで著者は，以上諸学者の業蹟、説を参考にし，一 万では癌腫組織像の多様性に繿み，全体的にみた組織清 成の状況を観察，他方では実質と間質との相互関係及び 実質並びに間質における諸形態学的態度を観察，併せて それらの各種所見と術後予後との比較検討を試み, 覀性 度判定の基潐を求めようとし, 若干の興味ある知見を得 たので，その概略を報告する次第である。

\section{第 2 章 検索材料及び検索方法}

第 1 節 検 索枌料

検索材料としては, 名大及び名市大耳藇咽焐科教室に 打いて，過去 13 力年間に手術された上癌癌剔出徱本の 内36 例を用いた，前述せる如く，大小種々の癌塊片とし て剔出されている標本が多いので，これら各癌塊片より 可及的多数のパラフイン切片を作成し, 主としてへマト キシリン・ェオジン重染色を中心に検索した。

第 2 節 癌組織像の分類

上頡癌組緆にみられた各種の組䌬像を概ね田内氏に従 つて分類した。

（1）表皮癌像：角化の強いもの，弱、もの，全く角 化を見ずして所講棘細胞癌像等を示するの.

（2）定型的腺癌像：癌細胸沍飞横に密接して腺腔 構造を形成し，間質との形態学的関連性はむしろ粗であ るむの.

(3) 非定型的腺渻像：腺腔形成は明らかであるが， 癌細胞は大小门形，紡錘形，不規則多角形。梨子形，柅 棒状等々で,癌細胞相互の形態学的関連は粗であつて，間 質とは密接な形態学的関連を有しているるの. (第 1 図)

（4）紡鍾形細胞癌像： 紡鍾形の細胞よりなるもの.

\section{第 1 図}

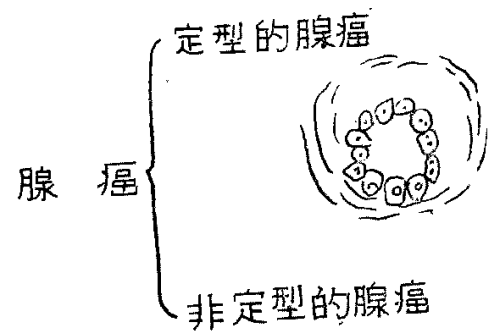

(田内)

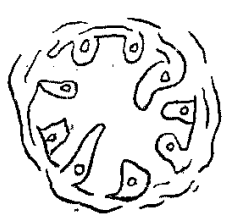

（5）単純藻像：いずれの上皮組織乃至 上皮細胞にも 類似を求め得ない上らな上皮性の細胞上りなるもの，上 記組䋨像のいずれにも該当しない上うなるの.

\section{第3 節 予後の分類}

臨㕅的観察で得た知見を基にして，上碞癌剔出衍後の 経過を次のように分けた。

（1）予後良㶩群：術後 1 力年以上生存したもの又は てているもの.14 例

（2）予後不良群：術後 1 年以内に死亡したもの. 22 例.

第 4 節 成績の検討

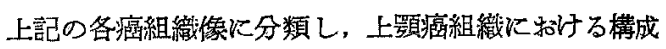
の発現の様相を 観察し，併せて予後をの関保を 検討し た。な招組織学的診断のみの判明しているものか゚ 25 例 あり，組織像検索に用いたもの 36 例に加えた計 61 例飞 ついては組織学的診断と予後とを比較するに止めたこ の際の組職学的診断は, 上述の癌組織像の内で, 最子優 位を示するのを診断名とした。

丈一方上䫑癌組繖の実質と間質との相互関係及び実質 並びに間質に扔ける諸形態学的態度を観察した。しかし て悪性度判定に対し，その基楚となる所見を把握するた めに，次の如き各項目について調查し，これらと予後と の関係を比較検討した.

(A) 解放像の有無:

解放像とは，所謂闌漫性浸潤癌像を呈しているすので 即ち癌細胞が，個トバラバラに間質内に浸潤した像を云 い, 癌細胞が間質との間に特に密接な形態学的関連を示 さない点で所謂非定型的腺癌像と明らかに区別乙得るこ 上は既に田内氏その他の認めた所である。この解放像を

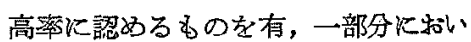
て認めるるのを中間, 全く認めないる のを無，の3段階に分類して検傠し 円枆形・立方形の細胞が互 に横に密接, 腺腔形成, 間 賀とは粗. た。

(B) 間質の態度:

(1) 間質発育の程度：間質結合織 の增生の程度.これを間質が極めて多 く，実質の少ない所楞硬性癌像を呈す るもの，あるいはこれに近いるのを良 好，問質が極めて少なく，実質が極め て多い所謂䯚梯癌像を呈するるの，古 るいはこ扎近いるの不良，その中 間のものを中間，と３段階に分類し た. 
（2）間質反応の程度：小円形細腿の浸潤の程度.こ れをその認められる程度により高度・中等度・軽度の3 段階に分類した。

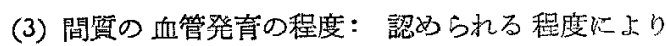
良好・中閒・不良の 3 段陵に分類した。

C) 実貿の態度 :

(1) 癌細胞配列の規則性の程度：これを規則的・不 规則的の 2 段階に分類した。

（2）多型像の程度：その程度により，高度・中等度・ 整度の 3 段階に分類した。

（3）核分剖像の頻度：顕微鏡倍率 400 倍で 5 視 野以 内に 15 以上の娄のを多い，5以下のむのを少ない。そ の中間学中等，の3段階に分頪した。

（4）過染性核出現の頻度：その頻度に上り多い，中 等，少ないの 3 段階に分類した。

（5）表皮癌胞栄に指ける角化度の程度：气の程度に より，高度・中等度・軽度の3 段階に分類した．高度と は存癌あるいはこれに近いもの，僌度とは非角化性表皮 癌即ち喖細胞癌像, 所謂璂底細胞癌像を呈するもの.

(D) その他の所見:

癌病栄に和ける出血・壊死・間質の硝子化等の発現程 度.これを無・有の2段階に分類した。

\section{第 3 章 検 索 成 績}

\section{第 1 節 組織学的䛦断と予告}

予後の判明しているうちで，組織学的䇏断の明嫔なも のは61 例あり，それらと予後之の比較は第 1 表の如く である. 即ち表皮癌は，良好群 16 例中 10 例（62.5\%）

第 1 表 組織学的䛦断と予後

\begin{tabular}{|c|c|c|c|c|c|c|c|c|}
\hline \multicolumn{3}{|c|}{ 組織学的診断 } & \multirow{2}{*}{$\frac{\text { 例数 }}{44}$} & \multirow{2}{*}{$\frac{(\%)}{(72.1)}$} & \multicolumn{2}{|c|}{ 予後良好 (\%) } & \multicolumn{2}{|c|}{ 予後不良 $(\%)$} \\
\hline 表 & 皮 & 癌 & & & 10 & $(62.4)$ & 34 & $(75.6)$ \\
\hline 单 & 純 & 癌 & 14 & $(23.0)$ & 4 & $(25.0)$ & 10 & $(22.2)$ \\
\hline \multicolumn{3}{|c|}{ 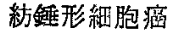 } & 2 & $(3.3)$ & 1 & $(6.3)$ & 1 & $(2.2)$ \\
\hline \multirow[t]{2}{*}{ 腺 } & & 癌 & 1 & $(1.6)$ & 1 & $(6.3)$ & 0 & $(0)$. \\
\hline & & & 61 & $(100.0)$ & 16 & $(100.0)$ & 45 & $(100.0)$ \\
\hline
\end{tabular}

不良 45 例中 34 例 $(75.6 \%)$ ， 単純癌は良好群 16 例中 4 例 $(25.0 \%)$ ，不良群 45 例中 10 例 $(22.2 \%)$ k見 ており，䇛群間に甚だしい差異を認めない。

所謂腺癌 (所謂定型的腺㴦) は1 例のみであるが，良 好群に見られ，紡錘形細䏲癌は备群に1例ずつ是られて いる。
即ら癌朣の在類と予後との䦌には一定の関係を見出し 得ないと云えるう。

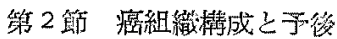

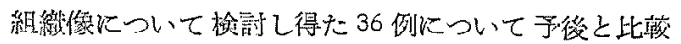
鶴察した。まず，それらの組織学的尉断上予後との関係 悌2表の如くで，たざ琵示するに止める。

第 2 表 癌組絨猜成憸討に用いた症例の内訳

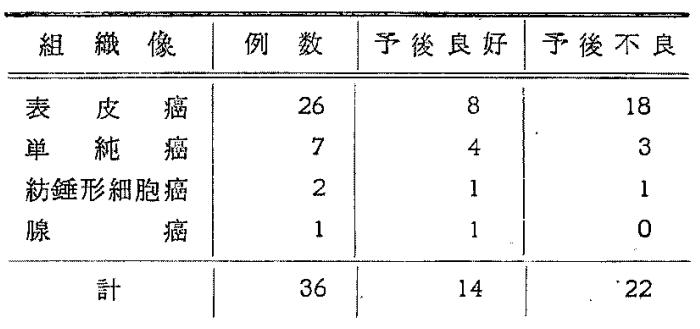

第3表上颚癌組織權成

\begin{tabular}{|c|c|c|c|c|c|c|}
\hline & 冱皮癌 & 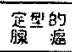 & 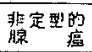 & 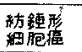 & 是神症 & \\
\hline 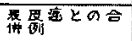 & $(16)$ & 1 & 8 & 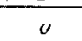 & 2 & \\
\hline 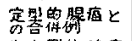 & 1 & $(1)$ & 0 & 0 & 0 & \\
\hline 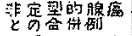 & 8 & 0 & $(0)$ & , & 3 & \\
\hline 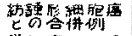 & 0 & 0 & I & $(\pi)$ & 0 & \\
\hline 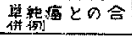 & 2 & $o$ & 3 & 0 & (A) & 計 $(\%)$ \\
\hline \multicolumn{6}{|c|}{ 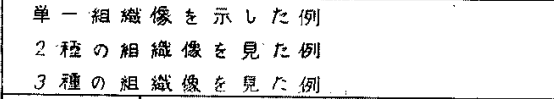 } & $\begin{array}{c}22(6 / .7) \\
13(36.1) \\
1(2.8)\end{array}$ \\
\hline 計 & & & & & & $36(100.0)$ \\
\hline
\end{tabular}

次に組織構成については第 3 表に示声如く，総数 36 例中 22 例!(61.1\%) 注篻一組織像を呈していた分， 14 例 $(38.9 \%)$ は 2 種以上の各癌組䅧像が合併してみられ ている.その内 3 種の組灤像の認められたものは 1 例 （36 例中 2.8\%）である. しかしてこれらの合併の様相 は，非定型的腺癌像之の合併例が最も多く，合併例総数 14 例中 12 例 $(85.7 \%$ ) の高頻度に認められ，12 例の非 定型的腺癌像との 合併例では表皮癌像との合併が 8 例 (12 例中 $66.7 \%$ ) で最も多く, 次いで単純癌像とが 3 例 (12 例中 $25.0 \%$ ) 紡銼形細胞癌像とが 1 例 (12 例中 8.3 \%)である.

単一組織構成をとるるの 22 例で忹表皮癌像が最も多

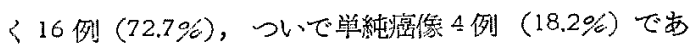
る.

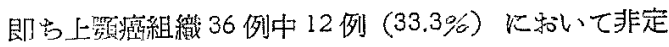
瑟的腺癌像との含併例を見出し，上颚癌組織像において もその 多情性がるとめ礼ると云充よう。しかしてこの 
第4表 癌組織㰌成と予挠

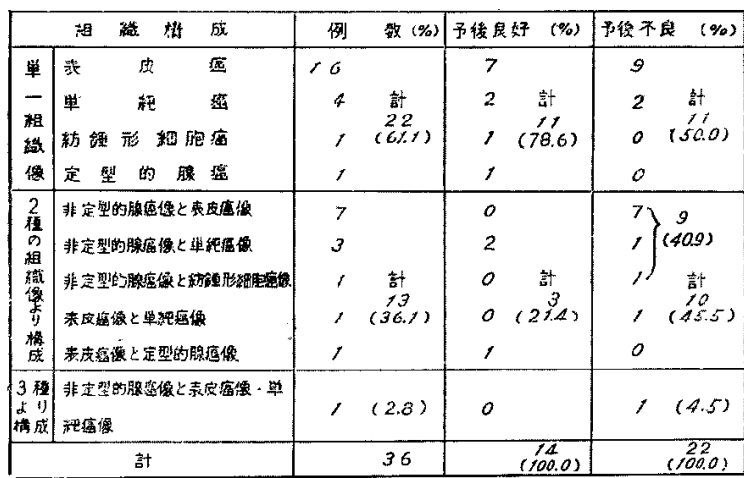

よう.

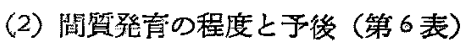
明確な関係は認められない。

(3) 間筫反応の程度亡予後（第 7 表） 间質反応が高度即ち，小円形細胞の浸潤が高度 なるのは予後性不良であり，予後との間に明らか な盖が見出される。

(4) 間筫の血管発省の程度と予後（第 8 表）

(5) 癌細胞配例の規則狌の程度と予後（第 9 竞)

以上 2 項目は，いずれる良好群之不良群との間 に差異を見出していないの恪表が示す通りであ る。

第 6 表

いて重愎して表示してある。

か子る組織像の多様性と予後との関係は, 籍 4 表に示 してあるが，良好群に拉いては，合併例が14 例中 3 例 (2.1.4\%) であり，しか子非定型的腺癌像との合併例は， 単純癌像との合併を 2 例みているのみで, 表皮癌像上の 間には，合併を元ていなく紊 14 例中 11 例 (78.6\%) が 革一組織像示していたのに反し，不良群においては， 22 例中 11 例 $(50.0 \%)$ 飞合併例見，乞の内非定型的 腺癌像之他癌組織像之の合併は9 例 (22 例中 40.9\%) あ り，特に非定型的腺癌像と表皮癌像との合併吕 7 例 (22 例中 $31.8 \%$ ) で最る多く見られた。 しかも11例の合併 例の内 1 例は単純癌像, 非定型的腺癌像，表皮癌像の 三者より構成されているのをみとめた. 又22 例中11 例 (50.0\%)は単一組織像を呈していた。

即亏非定型的腺癌像の認められた症例に，予後不良な 子のが多く，而かも表皮癌像との合併例に不良なるのが 多いと云えよ 5 .

第 3 節 実質並びに間質に和ける諸形態学的態度と 予後

(1) 解放像の有無と予後（第 5 表）

解放像の無いすのは予後良好であるが，一部に皮いて ざもこの解放像を示したものは予後が不良ですると云え

第 5 表

\begin{tabular}{|c|c|c|c|c|c|c|}
\hline 解放像の有無 & \multicolumn{2}{|c|}{ 例数 （\%) } & \multicolumn{2}{|c|}{ 予後息好 $(\%)$} & \multicolumn{2}{|c|}{ 可後不良 $(\%)$} \\
\hline 無 & 21 & $(58.3)$ & 12 & $(57.1)$ & 9 & $(42.9)$ \\
\hline 間 & 8 & $(22.2)$ & 1 & $(12.5)$ & 7 & $(87.5)$ \\
\hline 有 & 7 & $(19.4)$ & 1 & $(14.3)$ & 6 & $(85.7)$ \\
\hline
\end{tabular}

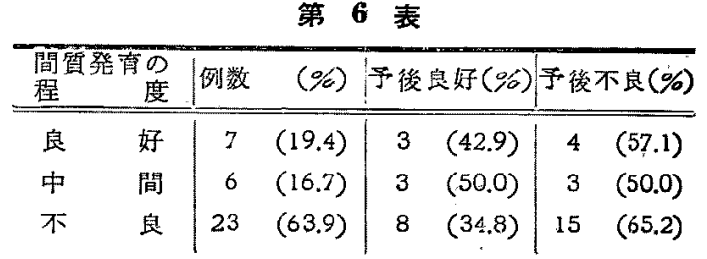

第 7 表

\begin{tabular}{|c|c|c|c|c|c|c|c|}
\hline \multicolumn{2}{|c|}{ 間留反応の } & \multirow{2}{*}{$\frac{\text { 例数 }}{16}$} & \multirow{2}{*}{$\frac{(\%)}{(44.4)}$} & \multicolumn{2}{|c|}{ 予後主好 $(\%)$} & \multicolumn{2}{|c|}{ 予後不良 (\%) } \\
\hline 軽 & 度 & & & 11 & $(68.8)$ & 5 & $(31.3)$ \\
\hline 中 & 度 & 2 & $(5.6)$ & 1 & $(50.0)$ & 1 & $(50.0)$ \\
\hline 高 & 度 & 18 & $(50.0)$ & 2 & (11.1) & 16 & $(88.9)$ \\
\hline
\end{tabular}

第 8 表

\begin{tabular}{|c|c|c|c|c|c|c|c|}
\hline \multicolumn{2}{|c|}{$\begin{array}{l}\text { 間䇫の血管 } \\
\text { 発茺の程度 }\end{array}$} & \multicolumn{2}{|c|}{ 例数 （\%) } & \multicolumn{2}{|c|}{ 予後良好 (\%) } & \multicolumn{2}{|c|}{ 予後不良 (\%) } \\
\hline 良 & 好 & 7 & $(19.4)$ & 1 & $(14.3)$ & 6 & (85.7) \\
\hline 中 & 間 & 4 & $(11.1)$ & 2 & $(50.0)$ & 2 & $(50.0)$ \\
\hline 不 & 皇 & 25 & $(69.4)$ & 11 & $(44.0)$ & 14 & $(56.0)$ \\
\hline
\end{tabular}

第 9 表

\begin{tabular}{|c|c|c|c|c|c|c|}
\hline $\begin{array}{l}\text { 癌稩菢配列 } 0 \\
\text { 規則性 } 0 \text { 程度 }\end{array}$ & 例数 & $(\%)$ & 承後 & 好 $(\%)$ & 㔔後 & 下良 $(\%)$ \\
\hline 規 刢 的 & 28 & $(77.8)$ & 12 & $(42.9)$ & 16 & $(57.1)$ \\
\hline 不規則的 & 8 & $(22.2)$ & 2 & $(25.0)$ & 6 & $(75.0)$ \\
\hline
\end{tabular}

第 10 表

\begin{tabular}{|c|c|c|c|c|c|c|c|}
\hline 多型像の & 程度 & 例数 & $(\%)$ & 予後 & 好 $(\%)$ & 予後 & 良(\%) \\
\hline 軽 & 度 & 11 & $(30.6)$ & 9 & $(81.8)$ & 2 & (18.2) \\
\hline 中 等 & 度 & 11 & $(30.6)$ & 3 & $(27.3)$ & 8 & (72.7) \\
\hline 高 & 度 & 14 & $(38.9)$ & 2 & $(14.3)$ & 12 & $(85.7)$ \\
\hline
\end{tabular}


(6) 多型像の程度と予後（第 10 表）

(7) 核分剖像の頻度と予後 (第 11 表)

（8）過染性核出現の頑度と予後（第 12 表）

第 11 表

\begin{tabular}{|c|c|c|c|c|c|}
\hline $\begin{array}{l}\text { 核分剖像の } \\
\text { 頻 }\end{array}$ & 例数 & $(\%)$ & 予後 & 好 $(\%)$ & 予後不良 (\% \\
\hline 少 & 17 & $(47.2)$ & 10 & $(58.8)$ & $(41.2)$ \\
\hline 中 & Il & $(30.6)$ & 4 & (36.4) & $7 \quad(63.6)$ \\
\hline 多 & 8 & $(22,2)$ & & (0) & $8(100.0)$ \\
\hline
\end{tabular}

第 12 表

\begin{tabular}{l}
$\begin{array}{l}\text { 過染性 核 } \\
\text { 出現の頻数 }\end{array}$ \\
\hline 少
\end{tabular}

以上の 3 項目は，いずれす中等度以上のものに予後不 良なものが多く，軽度なもの若しくは少ないものは予後 が良好であるのは各表が示す通りである。

（9）角化度の程度と予後（第 13 表）

（10）之の他の所見之予後（第14 表）

第 13 表 （表皮癌 26 例）

\begin{tabular}{|c|c|c|c|c|c|c|c|}
\hline \multicolumn{2}{|c|}{ 角化度の程度 } & \multirow{2}{*}{$\frac{\text { 例数 }}{18}$} & \multirow{2}{*}{$\frac{(\%)}{(69.2)}$} & \multicolumn{2}{|c|}{ 予後良好 (\%) } & \multicolumn{2}{|c|}{ 予後不良 $(\%$} \\
\hline 軽 & 度 & & & 5 & $(27.8)$ & 13 & (72. \\
\hline & 度 & 3 & (11.5) & 2 & 66. & 1 & $(00.0)$ \\
\hline 高 & 度 & 5 & (19:2) & 1 & $(20.0)$ & 4 & $(80.0)$ \\
\hline
\end{tabular}

第 14 表

\begin{tabular}{|c|c|c|c|c|}
\hline その他の所見 & 例数 & $(\%)$ & 予後艮好 $(\%)$ & 予後不良 (\%) \\
\hline 㭧 & 17 & $(47.2)$ & (35.3) & $(64.7)$ \\
\hline 有 & 19 & $(52.8)$ & $8 \quad(42.1)$ & $11 \quad(57.9)$ \\
\hline
\end{tabular}

以上 2 項目は，いずれる良好群之不良群上の問に，一 定の関係恃見出さ机ない。

\section{第 4 章 総括並びに考按}

第 1 節 癌跬組織像と予後洞関寸る文献的考察

代表的なむのについて聊か，考察を加える上，開発 2)

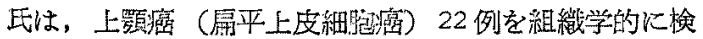
討し, 次の如く述べている.

（1）增殖細胞の間質内浸入発等の傾向強いむの. 癌細胞配列状態の不䙺則なもの. (3) 癌栄内の円形細胞
浸潤独いもの.（4）角化度の少ないもの.(5) 核の形態 の不整，大いさの不整，過染色症のもの忙悪性度が大で あるとし，(1) 実質及び間質の量的比，(2) 癌美の粗密

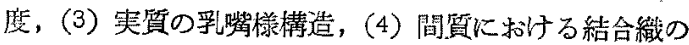
粗密度，血管の新生，円形細胞の浸㧚等は予後之の間に 一定の関係を示さない之述へ，烈性度判定を Haagensen 氏分類法及び Greenough 氏分類法を以て決する 際には充分な考虑が必要であると論じている。

山本 ${ }^{1)}$ 氏は，23 例の組職像定恰討した結果上䫍癌の 予後の決定を組織学的所見のみにたよることは不可能で あり，臨床所見によつても左右されるので，上颚癌の悪性 度を国虏の発生部位及び摭大の良否，組職学的所見及び 蒜移つ有無と位置によつて分類するのが適当であると し，婳㕌の部位については内側壁発生のものを第 1 度 $\left(L_{1}\right)$ ，後側壁，眼窩底，洞底に発生せるものを第 2 度 $\left(L_{2}\right)$ ，節路蜂巢及び间外軟部に波及せるものを第了度 $\left(\mathrm{L}_{3}\right)$ と定め，組織学的昰性度に就いては，乳嘴様癌及 び基底細胞癌を第1度 $\left(M_{1}\right)$, 角化性扁平上皮癌及び腺 癌を第 2 度 $\left(M_{2}\right)$ ，非角化性扁平上皮癌第 3 度 $\left(M_{8}\right)$ と規定，䩓移に就いては，颚下腺（顎下リンバ節）に転 移あるものを第 1 度 $\left(\mathrm{m}_{1}\right)$ ，浛下腺（顎下シン八゙節）以 外の遠滆部に転移あるものを第 2 度 $\left(\mathrm{m}_{2}\right)$ とし以上三要 弥の棕合結果を第 15 表の如くを之，覀性度表と名つ けている、しかして悪性度第 1 度 a 性予後最良く，

第 15 表 悪性度表 (山本 ${ }^{1}$ )

\begin{tabular}{|c|c|c|c|}
\hline 悪性度 & 部位 & 癌の種類。 & 転 \\
\hline l ${ }^{a}$ & $\begin{array}{l}\mathrm{L}_{1} \\
\mathrm{~L}_{2}\end{array}$ & $\begin{array}{ll}M_{1} \text { 又は } & M_{2} \\
& M_{1}\end{array}$ & \multirow[t]{2}{*}{$\begin{array}{l}\text { 転移なむむの，又は } \\
\text { あって } \mathrm{m}_{1} \text { のすの }\end{array}$} \\
\hline $\begin{array}{l}\mathrm{a} \\
\mathrm{b}\end{array}$ & $\begin{array}{l}\mathbf{L}_{1} \\
\mathrm{~L}_{2}\end{array}$ & $\begin{array}{c}M_{3} \\
M_{2} \text { 又仕 } M_{3}\end{array}$ & \\
\hline III $\begin{array}{l}\mathbf{a} \\
\mathbf{b}\end{array}$ & $\begin{array}{l}\mathrm{L}_{3} \\
\mathrm{~L}_{3}\end{array}$ & $\begin{array}{ll} & \mathrm{M}_{1} \\
\mathrm{M}_{2} & \text { 又は } \mathrm{M}_{3}\end{array}$ & $\begin{array}{l}\text { 転移なきむのあるも } \\
\text { の，又は } \mathrm{m}_{2} \text { のむの }\end{array}$ \\
\hline
\end{tabular}

\begin{tabular}{|c|c|c|c|}
\hline 悪 & 慰 & 泉 & $\begin{array}{l}\text { 不良後 } \\
\text { 例 }\end{array}$ \\
\hline \multirow[b]{2}{*}{ I } & $\mathbf{a}$ & 1 & 0 \\
\hline & $\mathrm{b}$ & 1 & 0 \\
\hline \multirow[b]{2}{*}{ II } & $a$ & 0 & 0 \\
\hline & $\mathrm{b}$ & 1 & 1 \\
\hline \multirow{2}{*}{ 杖 } & a & 3 & 1 \\
\hline & $\mathrm{b}$ & 1 & 14 \\
\hline
\end{tabular}


第回度 b蛙後最む不良なるのであるとしている。

今井 19) 氏は，口腔領域癌 (特化舌癌)，喉頭癌，乳癌， 子宮癌，胃癌 509 例火ついて,癌塊構築的な立場より,癌

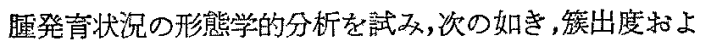
び CPL 分頪を提唱し術後転帰との関係を述べている.

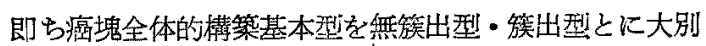
し，簇出の程度を，軽度のものを第 $\mathrm{l}$ 度，高度のもの を第り型と 5 段階に分け，舌癌，喉頭癌についての結果 では，無簇出型あるいは軽度簇出のるのは予後が良好 で，第 $\mathbb{1}$ 目度簇出型の多くは予後不良であると述へて いる. 文癌塊全体として，その発青先端部における実質

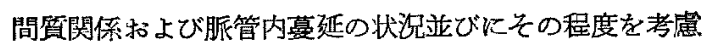
飞入れ，CPL 分類を提唱されている. 即ち発育先端部 飞結合譈性間質の「新生」を伴うるのを C 型 (cirrhotic form) と，簇出型癌塊で，その簇出部先端の 1 部な いし大部分に和いて，間質結合僟新生を伴ならことな く，多少河拘放らず低分化的の癌実質 (癌細胞) が組織 閒隚を增殖するのを認めるものを P 型(進行型 progressive form). 又癌細腿がリンバ管㐫るい細静脈内 を充し，增殖蔓延しつ〉もる像を示すものをL型（脈 管内蔓延型 lymphatic and blood-vessel-permeation form）と規定し， P 型・L 型を夫々その程度に応じて， 前者は 3 段階, 後者は 5 段階に分類し, 胃癌・喉頭癌・ 舌癌等に打いて，予後との関係を観察し，殊汇霄澏に括 いてはP・L を欠く C 型かるるいは軽度なるのが予终 が良好で方るが，舌癌・皖頭癌の手術例では術後遠隔成 樍は癌実質の筷出性発育程度二密接な関係を示し，CPL 分類はそのま〉適用されるに至らないと迹べている。

以上の如く織租像と予後との関佰についての業蹟は甚 だ多彩であり，門一する所を知らない現状であり，いず れがより妥当的，普僬的であるかは今後の検䛅にあちた いと思5.

その他喉頭癌に打放織租像と予後との関係について は岩本 ${ }^{(1)}$. 日比野，加藤氏 目) 等多くの学者が論じている。

第 2節 組織学的䛦断と予後

租織学的診断の明砝なるの61例について比較検討し たが，予後との間には一定の関係を見出し得なからた。 この点に関しては，浅井 6) 氏は，病腫の種類と治瘉浚

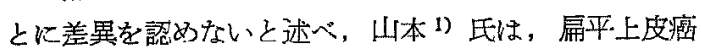
の予後は一般に不良のむのが多いとし，学者により，尺 の見解に一致を見ていない。

第3 節 癌組織構成と予後

癌組济像の示す多様性に関しては多数の学者の指摘し
ている所であり，姝に肺臊癌に私いては甚しく多様性に とんでいることが，田内2゙等よつて諭ぜられている。

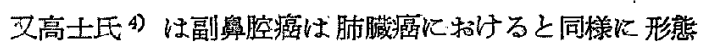
学的に多㥞な組織像を呈すると述べている.しかして,

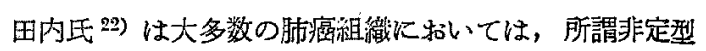
的腺癌像各基本型と考号られ, 表皮癌, 定型的腺癌, 单 純癌，多形細胞癌等々の組澈構成の多くのものは，この 所謂非定型的腺癌像よりの由来移行を推定せしめ得る. この場合他癌租織像からの非定型的腺癌像への移行を否 定する根拠を持たないが，いずれにしても多くの癌租織 像が非定型的腺癌像と密度な生物学的関連の存すること は否めないと述べ，又田内・传藤氏 25！6）は副鼻腔癌並 びに搌頭癌の手術例之剖検例とについて, その組絊構成 を検討した結果，非定型的腺癌像を始め各種租䋨像より 構成されている多様性を認めている．更に田内・佐藤氏 25）は肺臓癌の場合の非定型的腺癌像の 意義について, 肺葴癌以外の胃癌・子宮癌・膵癌・胆管癌・乳癌・皮唐 癌乞の他多数の癌䭪剖検例・手術例によつて詳細な再検 詩を試みている。即ち非定型的腺癌像の発現は一般に手 術例に稀で剖檢例にしばしばである点, 及びそれらの組 變学的所見から，非定型的腺癌像は他の各程癌租䋨像加 ら癌蕾発育の過程に与いて形成されると結論し，この非 定型的腺癌像の示す生物学的意義について詳細に考察し 興味ある知見を述べている。

著者るか子る癌組織像の多様性飞鑑み，上颚癌組䅧構 成を検討した結果，やはり各西癌組織像より構成されて いる場合が多いことを見出した. 即ち総数 36 例中 14 例 (38.9\%) に各種癌組織像が 2 柍以上合併しているのを 認め，又了穗の組織像のみられたるのを1例見出した。

しかしてこれら合併の様相は非定型的腺癌像と他癌組織 像との合併を最す多く 12 例（合併例総数 14 例中 85.7 $\%$ ），乙の内表皮癌像との合件を 8 例 (12 例中 66.7\%)

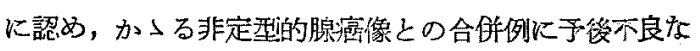
ものが多いことを知り得た。

第 4 節 実質並びに間質に拝ける諸形態学的態度 亡予後

従来の見解之不一致なものがみられた。例えば，角 化度と予後とについては，日此野，扣藤氏 ${ }^{24)}$ は36 例

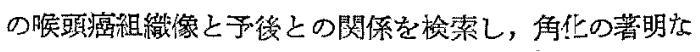
すの程予後は良いと述べ，上顎癌に执いて開発氏2 女 㕛角化度大なるものは比較的良好な経過をとつたと述べ

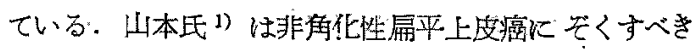
ものは予後不良で角任の良好なるのは予後がよいが，角 
化の最も強いものにあつても予後が必ずしも良好でない 例外的存在が認められたと述べている．乙かし著者の検 索例に和いては，角化の程度の謌いもの程予後が不良で あることは從来の報告と一致しても，良好执いても 多くのるのは，角化の程度が弱いという矛盾した結果を 得た. 取り技つた症例の美異にもよるとは思らが，検索 者によつて結果が一致しないといらことは，角化度は予 後に特別に関係が梁い因子であるとは云い切れぬのでは なからうか。

間質反応としての小円形細胞浸潤は癌腫增殖の際の二 欢的変化であると解せられている.著者の検索例では， 罣度の高度なるのは予後が不良といら結果を得たが，こ のことは，癌䭪発育の旺盛なるのに二次的変化が多く， 従つて，予後る不良であると解したい，

解放像の有無については実質細胞が間質の内湳漫性 淩潤寸る像が翟められないもの程予後が良好であり， 逆に一部においてら゙す認められるむのは予後が不良とい ら結果を得, 開発氏のの観察例と一致していた。

その他，多型像の程度，核分剖像の頻度，過染性核出 現の頻度については，いずれるその程度高度なるの程及 その頻度多いもの程予後が不良であるという結果を得， 開発 2). 日比野，加藤氏 29) 等の報告と一致している.

\section{第 5 節 悪性度判定基準}

以上の検討から著者は，予後に関係があるとみなされ る項目は，

（1）解放像の有無，(2) 間質反応の程度，(3) 癌細胞 の多型像の程度，(4) 核分剖像の頻度，(5) 過染性核出 現の頻度の 5 項目であることを知つた。この結果から次 の如き悪性度判定基準を設けた。

要性度第 I 度：以上 5 項目の内いずれか4 項目が 軽 度若しくは少ないものあるいは認められないもの。

悪性度第四度：以上 5 項目の内いずれか 4 項目が高 度若しくは多いるのあるいは羿められるもの，

覀性度第 II度：第 I 度・第四度以外のもの.

以上の 3 つの段階分類し，この度数の多いもの程徳 性度が強いと考えた。

第 16 表

\begin{tabular}{ccc|cc|cc|cc}
\hline 悪 & 性 & 度 & 例数 & $(\%)$ & \multicolumn{3}{|c}{ 後良好 (\%) } & 予後不良(\%) \\
\hline \hline 第 & I & 度 & 11 & $(30.6)$ & 9 & $(81.8)$ & 2 & $(18.2)$ \\
第 & II & 度 & 18 & $(50.0)$ & 5 & $(27.8)$ & 13 & $(72.2)$ \\
第 & II & 度 & 7 & $(19.4)$ & 0 & $(0)$ & 7 & $(100.0)$
\end{tabular}

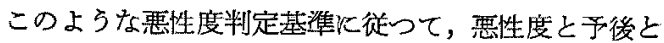
の関係をみると第16表に示如く，悪性度の少ないも の程予後が良好であるのを認めることができる。

か今る悪性度判定基準潽温性, 妥当性があるか否か は，今後の検討を必要とすることは云うまでるなく，た だ単にこの著者の悪性度判定基準のみによつて凡ての予 後を律し得られない場合も㞗ふであるらことは勿論であ る.

\section{第 5 章 結 論}

(1) 上䫑癌61例について観察した結果では癌蹧の稙 類と術後経過との間に一定の関係を見出し得ない.

(2) 上顎癌剔出標本 36 例について 組織構成を 检討し た結果， 22 例 (61.1\%) は単一組織像を呈し，13例 (36.1\%) 'は2 種の癌組織像が合併し1例 $(2.8 \%)$ は 3 種の癌組織像より構成され 多彩な組織構成を示してい ろ.

しかして組縞構成の様相は，所謂非定型的腺癌像（田 内）之の合併例 35 最子多く，合併例総数 14 例中 12 例 (85.7\%)であり，その内訳は，表皮癌像との合併が 8 例(12 例中 $66.7 \%)$ ，単純癌像之の合併が 3 例（12 例中 $25.0 \%$ )，紡鐯形 細胞癌像之の 合併方 1 例 (12 例中 8.3

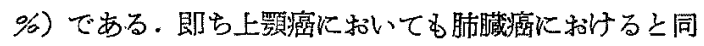
じような，澏組織像の多様性を諗め得る。

（3）術後経過不良群 22 例中 10 例，(45.5\%) は2 存の 癌組織像より構成され，1例 $(4.5 \%)$ は 3 種の癌組織像 上り構成され，その内所謂非定型的腺澏像之表皮澞像上 の合併が 8 例 (不良合併例稜数 11 例中 $72.7 \%$, 不 良群 22 例中 $36.4 \%$ ) である。

これに反し，良好群に和いては，14 例中，3例（21.4 \%）に合併例を見出したのみで，しかも非定型的腺癌像 と表皮癌像との合併は1 例子ない，

即ち癌組織像の多様性と術後経過との間には密接な関 係があり，多様性なもの程予後は不良である。文所謂非

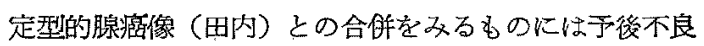
なものが多い。

（4）1. 解放像の有無，2. 問質反応の程度，3. 癌細胞 の多型像の程度，4. 核分剖像の頻度，5. 過染性核出現 の頻度の5 項目が術後経過と関係を有することを認め， 独自の惩性度判定基潐を定め, 組織学的に予後を推定寸 る扰り所とした。しかしかっる基蕉が妥当的且普遍的 であるか否かは今後の充分な㭘討を必要とする所であ る。 


\section{主要文献}

1) 山本：耳院科，21；5，190（昭 24）。2)開発：十 全会誌，49；3，465，(昭 19），3）石倉：日耳奥，49； 11，987，(昭 18．4) 高士：瘦，46；2３，321，(昭30． 5）茫，久島，馬場：癌，42；2 4, 160（昭26).,43；2 3,

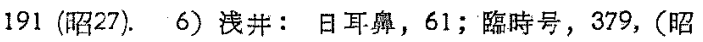
33）。 7) 田中（文）：日耳鼻，25；3 4, 152，(大 8,9．

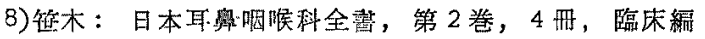
各諭团，243頁，(昭 30)，9）緒方：虚，30；5，689， (昭 11)，10）後藤. (光), 浅井, 三吉：癌， $45 ； 192$, （昭 29），11）赤崎：日座㛺誌，5；7，699，(昭 28). 12）今井：福岡医会誌，45；2，72，(昭 29）。.13）侕

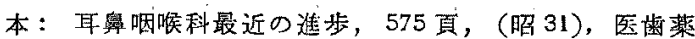
出版発行。 14) 吉田：8上り引用。15) 吉田：13 上り引用. 16) 岩本：耳喉科，22；8，329，(昭 25). 耳喉科, $23 ; 5,179$ ，(昭 26).117) 所, 斎藤：癌, $41 ； 65$, (昭 25).18) 岡本: 医学研究，23；2,257, （昭 28）. 19）江浦：福岡医会誌，47；3，265，（昭

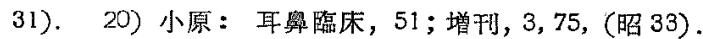
21）三吉：耳鼻臨床，48；6，404（昭 30）。22）田内 他：名市大医誌，5；3，83（昭 29）。23）太田，田中： 癌，42；181，(昭 26)，24）日比野，加藤：現代医 学，3；2，117，(昭 28). 耳率臨床，46；11，772，(昭 28). 46；12，817, (昭 28). 25) Hisashi TauchiTsuneko Sato: Nagoya Med. J. 4: 3-4, 155, (1958)'

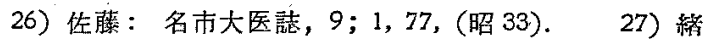
方, 三田村：病理学総諭下の巻, 946 頁，(昭 11)，南山 堂発行. 28) 宮地：臨床組織病理学, (昭 31), 杏林

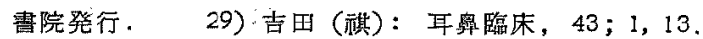
（昭 25）.30) 佐伯：東京医会誌, 52；1 6, 191，(昭 13). 31) 斎藤：東医科誌，9；4，54（昭 26)，32） 榐谷, 星野: 綜合医学, 12；8, 1555, (昭 30).33) A.C. Broders: Jour. A.M.A. $74:$ 10, 656, (1652). 34) Hisashi Tauchi: Nagaya Med. J. 3: 1, 1, (1955). 付图説明

凡て、へマトキシリン・エオジン重染色
凡て, 顕鏡倍率 $\times 200$

第 1 図，第 2 図

所賙非定型的腺癌像（田内）(肺臟癌)

第3 図，第 4 㘡，第 5 図，第 6 図

症例 No. 44,52 古 左

第 3 図：表皮癌像を是する部位

第 4 図：輠細胞癌像を是寸尚部位

第 5 図，第 6 图：非定型的腺虎像を是吉当部位 第 7 图, 第 8 図

症例 No. 38,63 우 右

，第 7 目：紡鋌形細胞瘦像を星する部位

第 8 図：非定型的腺癌像老是卞る部位 第 9 図, 第 10 図, 第 11 図, 第 12 図

症例 No. 22,57 合 左

第 9 図：表皮癌像を是する部位

第 10 図：䊂細胞癌像を呈する部位

第11 图，第 12 図：非定型的腺癌像呈要る部位

稳を䅂るに監み，御指導・御校閲を睗つた後 藤教授・田内教授及び松田教授に梁甚なる謝意 を表す併せて種くの御支援を睗わった名古屋 市立大学及び名古屋大学耳嚊咽喉科教室高須助 教授・三宅助教授・馬場酸吉氏並びに教室員各 位に謝意を表す

本論文の要旨は日本耳鼻咽喉科学会東海地方 会第 152 回例会（昭 31.3 ), 第 18 回近竭耳鼻咽 喉科学会 (昭 31.4)，日本耳奥咽唉科学会第 57 回総会(昭 31.6)，日本耳奥咽喉科学会東海地 方会第 154 回例会（昭 31.7)，第 19 回近繁耳鼻 咽喉科学会 (昭 31.9)，第 4 回中部地方逨合会 （昭 31.10）並びに名古屋市立大学医学会第.7. 回 総会（昭 31.12）に出いて演説した。

（原稳到着 $=$ 昭和34.10.20日） 
舊 論文付図 (I)

第 1 図

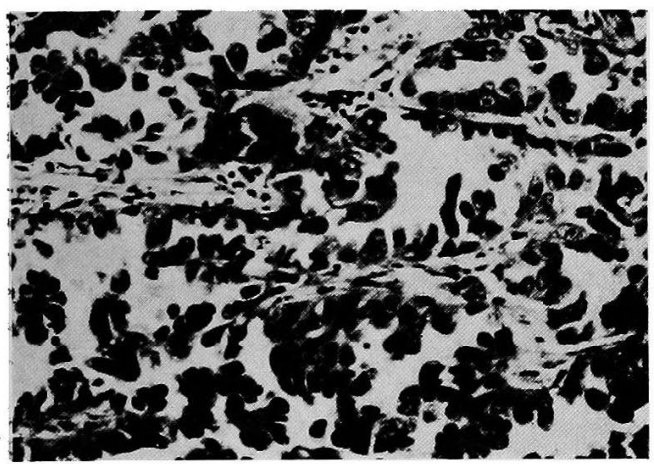

第 3 図

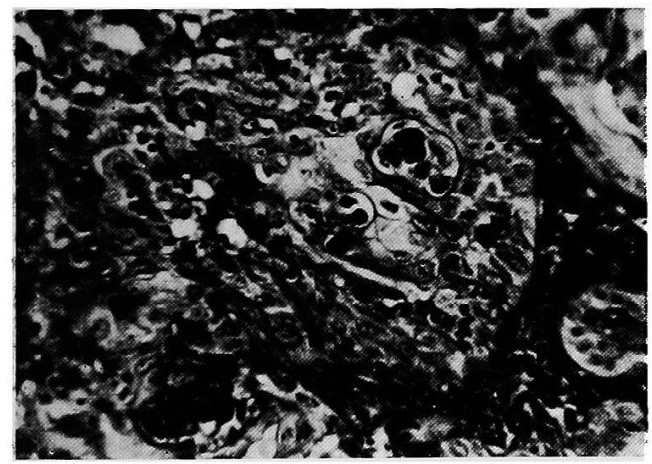

第 5 図

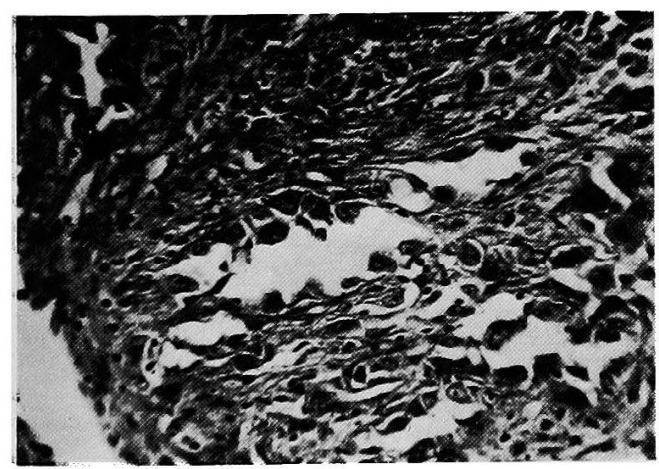

第 2 图

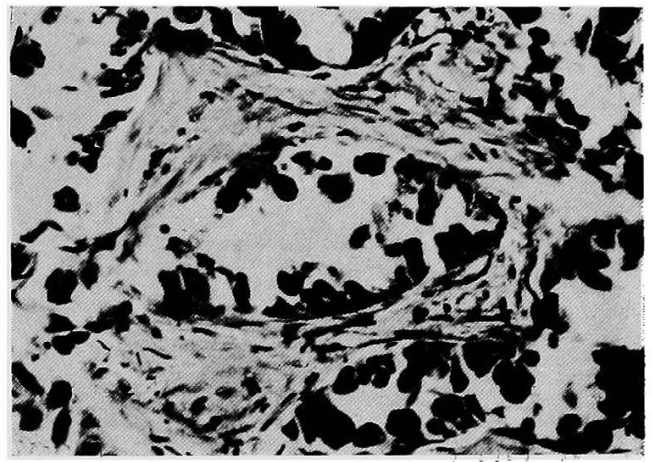

第 4 図

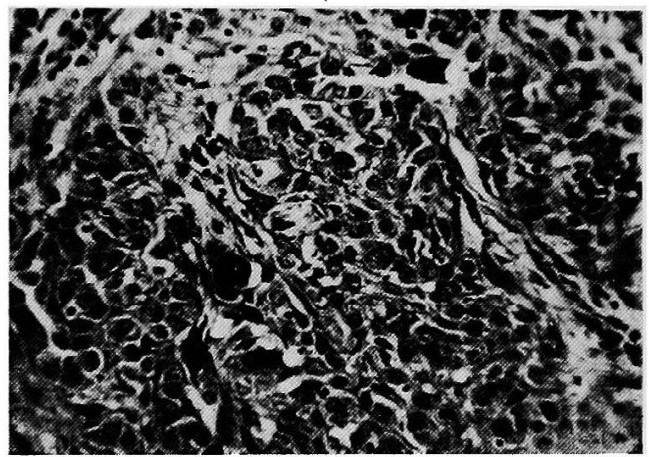

第 6 図

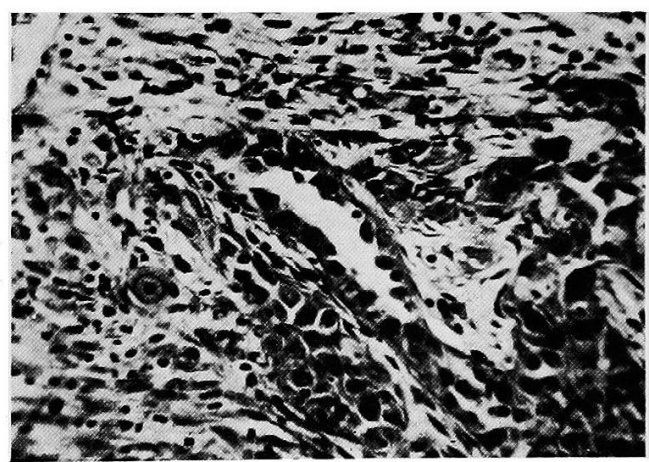


第 7 図

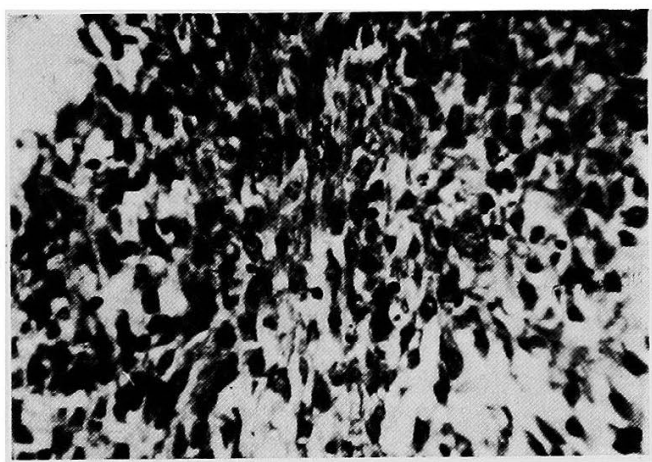

第 9 図

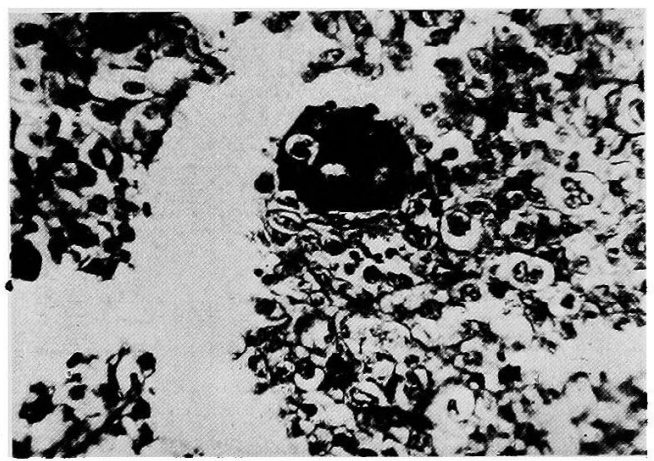

第 11 図

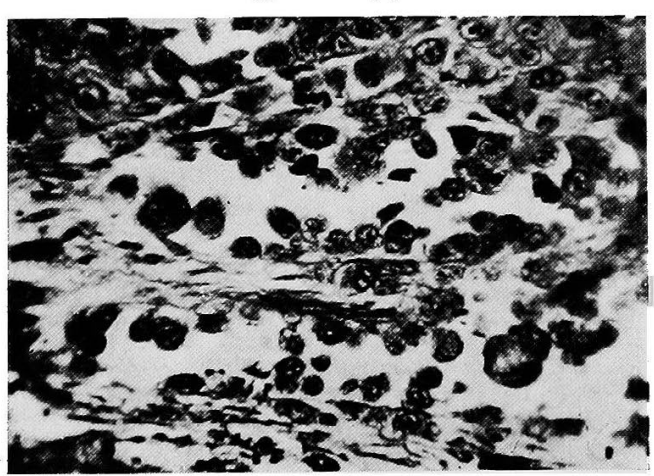

第 8 図

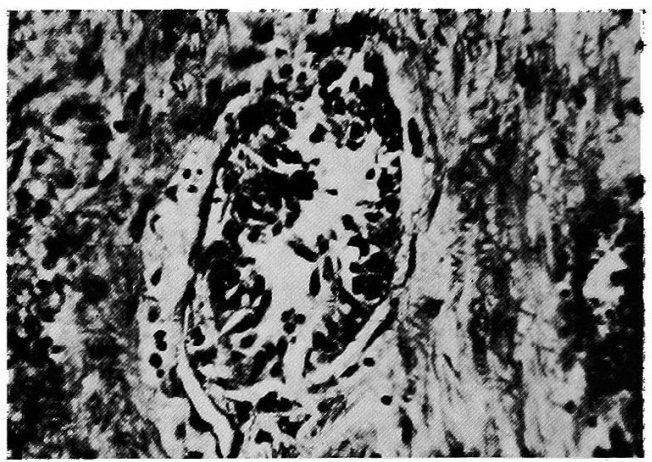

第 10 図

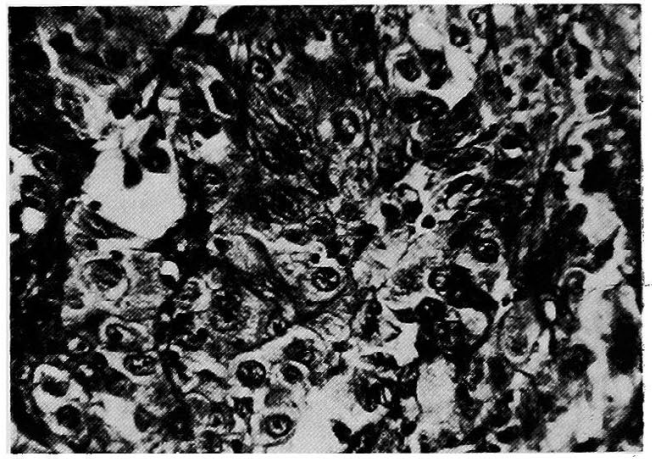

第 12 図

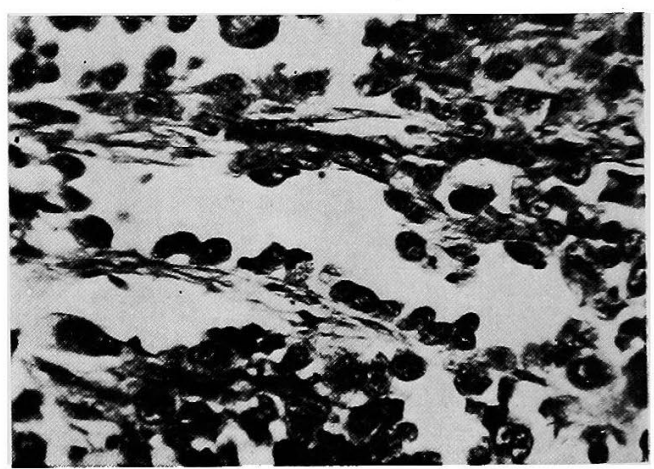

